\title{
The financial and prudential performance of Chinese banks and Fintech lenders in the era of digitalization
}

\author{
Paraskevi Katsiampa $^{1} \cdot$ Paul B. McGuinness ${ }^{2,3}$ (D) Jean-Philippe Serbera ${ }^{4} \cdot$ Kun Zhao $^{5}$
}

Accepted: 14 November 2021 / Published online: 15 January 2022

(c) The Author(s) 2022

\begin{abstract}
The years 2013 to 2019 marked an explosion in Fintech in China. We analyze the financial and prudential performance of 40 exchange-traded banks and 25 listed Fintech lenders in China during this watershed period. Among other things, traditional banks experienced rising operating costs, declining profit margins and softening loan quality. Consistent with a process of adaptation, traditional bank performance stabilized in the latter part of the study period (2018-19) after an initial period of decline. Study findings also highlight rising business and regulatory costs for Fintech providers over the course of the study frame. A marked deterioration in online lenders' Special Mention and Non-Performing Loan (SML $\&$ NPL) positions arose during the period. Within the traditional bank group, smaller entities with fewer growth options and greater foreign ownership fared worst in prudential terms. Traditional banks' financial and prudential performance also declines with time since IPO. Relative to joint stock commercial, city and rural banks, state-owned lenders registered more resilient performance, especially in relation to asset quality. In a final area, we construct a categorical Fintech proficiency variable for China's established banks. Our preliminary evidence suggests such proficiencies help stabilize SML and NPL rates and support financial returns. Overall, we offer major contribution to the banking literature by analyzing the financial and prudential performance of both incumbent and emerging lenders in one of the world's most dynamic Fintech settings.
\end{abstract}

Keywords Financial technology (Fintech) · Prudential success - Special Mention Loans $(\mathrm{SMLs}) \cdot$ Non-Performing Loans (NPLs) · China $\cdot$ Financial returns $\cdot$ Private versus state ownership $\cdot$ Foreign equity ownership $\cdot$ Time since IPO

JEL Classification C23 · G21 $\cdot$ L25

Paul B. McGuinness

mcguinne@baf.cuhk.edu.hk

Extended author information available on the last page of the article 


\section{Introduction}

Chinese banks witnessed massive and unprecedented challenge from Fintech lenders in the recent seven-year period, 2013-19. The present inquiry assesses the financial and prudential performance of China's leading exchange-listed bank and Fintech entities during this period of disruption. We pursue this enterprise through comparison of 40 traditional banks and 25 emerging Chinese Fintech lenders. This study highlights Chinese banks' growing adaptation to digitalization, as well as the rising costs and regulatory hurdles confronting new Fintech entrants.

The current enterprise extends pre-digitalization era accounts of Chinese bank performance (García-Herrero et al. 2009; Sun and Chang 2011; Tan and Floros 2013; Zhang et al. 2013; Li and Wang 2015; and Tan 2016). First, we consider the impact of digitalization on the performance of incumbent players. Second, we benchmark such performance against competing and emerging Fintech entities. Third, we assess both groups in relation to their prudential and financial performance. Fourth, we identify the ownership (i.e., state vs. non-state, domestic vs. foreign), investment profile and risk characteristics of incumbent banks in relation to such performance. Fifth, we construct a categorical measure of established banks' Fintech capabilities. In this way, we assess such banks' adaptation to digitalization.

Fintech disruption has been rapid and far-reaching in China. In transactional terms, China is now an almost cashless economy (Aldama 2017). Traditional Chinese banks' core profit areas have faced major challenge from payment platforms, as well as from wider digitalization networks and ecommerce providers. In funding terms, such platforms and providers directly challenge traditional banks' retention of depositors. On the loan book side, developments in crowdfunding and "Peer-to-Peer" (P2P) lending threaten banks' core business lines. Digitalization also undermines banks' conventional "face-to-face" position in consumer finance and wealth management. Such multifarious challenges have forced traditional banks to develop and/or acquire Fintech proficiencies (Aggarwal 2020). In recent years, a majority of Chinese financial institutions have invested-in Fintech partnerships, joint ventures and alliances. ${ }^{1}$ Naturally, such initiatives further extend and deepen pre-existing digitalization trends.

The principal contributions of this paper are fourfold. First, we explore the extent to which virtual banks and other Fintech providers have effected change in incumbent banks' return-on-assets (ROA) and return-on-equity (ROE) performance. The paper's second focus area addresses bank performance in prudential terms. Specifically, we explore the factors that underlie the maintenance and control of Chinese banks' Special Mention Loan (SML) and Non-Performing Loan (NPL) positions. SML rates offer clues on the possible migration of loans from performing to non-performing status. The Chinese state, and China Banking and Insurance Regulatory Commission (CBIRC) in particular, place great emphasis on asset quality. In the unique institutional and regulatory setting of China, a bank's NPL rate offers a highly-visible and widely reported barometer of prudential success. As Zhang et al. (2016) reveal, high NPL rates exacerbate moral hazard concerns, by incentivizing management to offer risky new loans. While such a strategy has a short-term positive effect, diluting existing non-performing positions and raising profits, NPL rates

\footnotetext{
1 To illustrate, PwC's (2017) survey of Chinese financial institutions reveals that 68 percent of respondents expressed an intention to enhance existing and/or cement new Fintech partnerships within five years.
} 
inevitably rise over the longer-term. Accordingly, the avoidance of systemic risk issues encourages regulatory targeting of NPL rates. Based on such reasoning, we assess Chinese bank performance in both financial and prudential terms. This approach significantly extends the narrative on Chinese bank performance which, for the most part, stresses financial returns (see, for example, Li and Wang 2015; Tan 2016; Fang et al. 2019). ${ }^{2}$

Digitalized lending platforms squeeze traditional bank income in a number of areas. Bain and Co.'s (2019) analysis reveals banks' global loss of retail customers to ecommerce and digital payment platforms. Specific to China, Klein (2019) highlights the rise of Alipay and WeChat in supplanting traditional banks' erstwhile dominance of consumer payments and finance. However, in some less contestable areas, such as wealth management, wholesale and corporate banking, the threat to incumbent lenders may not be so obvious. In effect, the picture is not entirely one of loss. In such a context, segmentation may arise in traditional bank and Fintech entities' client and customer pools. ${ }^{3}$ Fintech applications also offer profit opportunity for banks. One example is Big Data in credit evaluation and monitoring. ${ }^{4}$ In-house Fintech therefore provides a route to lower NPL rates (Cheng and Qu 2020). Improvement to a bank's NPL rates could thus arise even if Fintech disruption and competition weaken bottom-line outcomes.

Within our 2013-19 study frame, we document some deterioration in Chinese banks' SML and NPL positions. However, stabilization and/or reversal of this trend arose in the pre-COVID years of 2018 and 2019. In contrast, Fintech lenders experienced marked weakening of their SML and NPL positions between 2013 and 2018, with some indication of a slight reversal in this trend in 2019.

The third line of investigation examines changes in Chinese banks' management of costs and risks during the digitalization era. As a fourth important contribution, the present inquiry assesses the effect of bank ownership on both financial and prudential success. We assess whether state-controlled or privately-held banks fared better during the Fintech era. The present inquiry also examines whether significant foreign minority equity stakes in Chinese banks correlate with performance. Overall, the current research enterprise offers a topical and comprehensive account of the factors relevant to Chinese banks' financial and prudential success in the "New Normal" of disruptive Fintech innovation. Our study findings thus offer important prescriptive value.

In summary, we seek to explain four measures of bank and Fintech performance, two of which are financial (ROA \& ROE) and two prudential (SML \& NPL). We address the determinants of such measures for the 2013-2019 study period by considering China's 40 leading exchange-listed banks. For robustness reasons, we also benchmark against a separate group (of 25) exchange-listed Fintech entities with strong business presence in China. As important background, study findings highlight a general weakening of traditional Chinese banks' ROA, ROE, NPL and SML performance numbers during the 2013-19 period. The enveloping Fintech threat, and an environment of lower interest rates and declining lending margins, underlie this outcome. Within this context, larger banks appear more resilient. In relation to specific determinants, ratios for loan loss provisions, liquidity and

\footnotetext{
${ }^{2}$ Bailey et al. (2011) examine the financial and stock return performance of Chinese banks. For examination of the determinants of Chinese bank NPLs, see García-Herrero et al. (2009). Additionally, He et al. (2017) examine the factors underlying "impaired loans".

3 We thank an anonymous reviewer for guidance on this point.

4 One channel is through the production of finer-grained information on borrower creditworthiness. McKinsey (2014, p. 61) quantifies the advantage of Big Data in limiting NPL risks on loans to SMEs.
} 
dividend payout display inverse association with financial returns. Equity capital ratios exhibit the opposite. For NPLs, rates are increasing (and thus asset quality is decreasing) in a bank's foreign strategic ownership, equity capital and time since listing. Lower NPL rates are evident in banks with more growth options (i.e., higher market-to-book ratios) and greater dividend payouts. Traditional banks' financial and prudential performance both weaken with time since exchange listing. The sale of underperforming assets and the recapitalization of balance sheets in the run-up to IPO may underlie such outcomes (McGuinness and Keasey 2010).

This paper comprises five sections. Section 2 develops research hypotheses. Discussion of data and methodology follows in Sect. 3. Section 4 sets-out empirical findings. The first part of this section compares and contrasts the financial and prudential properties of China's 40 leading banks with 25 of China's leading exchange-listed Fintech entities. The remainder of Sect. 4 focuses on the multivariate determinants of bank and Fintech performance. Finally, Sect. 5 offers concluding remarks, policy prescriptions and future research directions.

\section{Background issues, literature review and hypothesis development}

\subsection{China's preeminent position in Fintech}

While banking innovation has been a recurrent theme of the last 30-40 years (Dermine 2016), recent changes are considerably more profound and challenge the very existence of traditional deposit-taking institutions (King 2018). It is thus timely to assess the impact of Fintech disruption on longstanding banks' operations, profitability and strategies. We address this issue within the context of one of the world's largest and most dynamic Fintech economies, China. Invasive competition from virtual banks, digital payment providers, crowd-funders and $\mathrm{P} 2 \mathrm{P}$ lending platforms has forced traditional banks in China to re-strategize and upgrade. In offsetting market share losses, Chinese banks have also responded with expenditures in new business areas, such as ecommerce. ${ }^{5}$ The Chinese government has also been a champion of strategic banking change, especially for its leading state-owned banks (Allen 2016).

Several important data points illuminate China's Fintech revolution. For example, KPMG (2018, p. 67) reveals that annual investment in Fintech investment in China through "PE, VC and M\&A" channels soared from around US\$115 million in 2013 to more than US $\$ 18.2$ billion in 2018. Preen (2018) reports that as of the 2015 year-end the overall market size of Fintech in China exceeded US\$1.87 trillion. As of the 2019 year-end, three of the globe's top-six Fintech companies were Chinese (see H2 Ventures \& KPMG, 2019). China also has more unicorn companies (i.e., private entities with value of at least US\$1 billion) than any other major jurisdiction (Hurun 2019), with Fintech as the major driver in such companies' ascent. ${ }^{6}$

\footnotetext{
5 For an early example, see Rabinovitch's (2013) analysis of China Construction Bank's entry into this space.

6 The adoption of Fintech by small to medium sized enterprises in China is almost three times rates evident for the US and UK (EY 2019b, p. 21). Moreover, the annualized growth in Fintech revenue in China has exceeded 40 percent for each and every year in the period 2014 to 2019 (see Statista, 2020, p. 6). Additionally, lending participants on online P2P networks in China grew from 0.30 million to 17.13 million between 2013 and 2017 (see Statista, 2020, page 9). As a further important data point, Zhao (2021) offers a
} 
In sum, the rise of digitalization imperils most if not all areas of traditional banking (King 2018). Chinese banks have responded swiftly to such challenges. We assess incumbent banks' adaptation in relation to their financial and prudential success throughout this recent period of banking transformation. This adaptation has taken place within a unique setting. First, Chinese banks operate in an almost cashless economy (Adama, 2017). Second, no matter whether state- or non-state owned, controlling bank stakes remain domestic. Third, regulated lenders also face competition from semi-regulated Shadow Banks. ${ }^{7}$ Fourth, and as set out in the foregoing, Chinese banks operate in one of the world's largest and rapidly-evolving Fintech domains. This last feature presents both profit opportunity and competitive challenge.

\subsection{Literature review and hypotheses}

Several studies have sought to identify the determinants of banking performance. The standard approach has been to measure performance in financial terms, usually in relation to ROA and ROE. For example, Neely and Wheelock (1997), Sharpe (1995), Altunbas et al. (2000), Dietrich and Wanzenried (2011) offer respective studies for the USA, Australia, Japan and Switzerland. ${ }^{8}$ Studies of Chinese banks also stress ROA and ROE performance measures (see, for example, Li and Wang 2015; and Tan 2016). Differences in institutional banking and regulatory practices, as well as macro and time period differences, explain the divergent outcomes evident in such studies. Nonetheless, some recurring themes emerge. We address some of the common threads below.

The relationship between risk management and bank performance has received considerable academic attention (see, for example, Athanasoglou et al. 2006, 2008; Brissimis et al. 2008; Sun and Chang 2011; Fiordelisi et al. 2013; Sturm 2013b; and McNulty and Akhigbe 2017). This literature stresses the importance of (1) credit, (2) liquidity, (3) capital, (4) operational and (5) market risks in relation to traditional banks' financial performance. We consider likely modulation in some of these associations during the recent period of Fintech disruption. Our investigation also deepens existing accounts by addressing prudential performance. We also extend the literature on conventional risk factors by applying them to the financial and prudential performance of virtual banks.

Credit risk is the first of the five risk dimensions investigated. ${ }^{9}$ Deterioration in bank asset quality weakens stock returns (Cooper et al. 2003). A bank's sound credit management also supports the stability of both the lender and the surrounding economy (Psillaki et al. 2010). Several studies identify an inverse credit risk-bank performance relation. ${ }^{10}$

\footnotetext{
Footnote 6 (continued)

case-driven approach in assessing the financial risk characteristics of 11 pairings of longstanding and "challenger" banks for each of three countries, Australia, China and the UK, in respect to the period 2013-17.

7 For quantification of the size of this sector, see Elliot et al. (2015, pp. 9-10).

8 Other highlights in this literature include Short (1979), Bourke (1989), Molyneux and Thornton (1992), Haron (1996), Demirguc-Kunt and Huizinga (2000), Athanasoglou et al. (2006), Altunbas et al. (2007), Pasiouras and Kosmidou (2007), Iannotta et al. (2007), Brissimis et al. (2008) and Sun and Chang (2011).

9 The Basel Committee on Banking Supervision (1999) stresses the objective of credit risk management is:

"to maximize ... [a given bank's] risk-adjusted rate of return by maintaining credit risk exposure within acceptable parameters".

${ }^{10}$ For example, Athanasoglou et al. (2006) analysis of SE European credit institutions reveals a significant negative relation between financial performance (ROA and ROE) and loan loss provisions. For newlyacceded EU countries, Brissimis et al. (2008) detect a significant inverse link between credit risk and productive efficiency. However, credit risk had an insignificant positive relation with net interest margins.
} 
Our first hypothesis thus asserts that increased credit risk weakens the performance of both bank and Fintech entities.

H1 (B \& F): Performance (both prudential and financial) has negative association with credit risk.

Liquidity risk is also widely emphasized in the bank performance literature. The diversification of loan portfolios and maintenance of high working capital levels attenuate such risk, especially in periods of great uncertainty (Brissimis et al. 2008). ${ }^{11}$ Empirical findings on the bank profitability-liquidity nexus are nonetheless mixed. Some studies identify positive associations (Athanasoglou et al. 2006; Bourke 1989; Haron 1996), while others report inverse associations (Molyneux and Thornton 1992; Goddard et al. 2004a; Brissimis et al. 2008; and Tan 2016). Pasiouras and Kosmidou's (2007) analysis of EU countries reveals negative and positive effects. They report significant negative (positive) links between profitability and liquidity for domestic (foreign) banks.

Liquidity provisions and holdings impose expenses and opportunity costs on banks (Bourke 1989, p. 76; Molyneux and Thornton 1992; and Eichengreen and Gibson 2001). This argument applies in respect to both traditional banks and Fintech entities. Accordingly, Hypothesis 2 asserts,

H2 (B \& F): Performance (both prudential and financial) has negative association with liquidity.

However, tight liquidity may not necessarily support performance. Megginson et al. (2014) report that state-controlled Chinese banks are able to hold low levels of cash because of "soft budget constraints". In effect, state-held banks are able to lobby the state for capital injections.

Capital adequacy is another internal measure relevant to bank performance. Higher capital levels, which reduce capital risk, act as a safety net (Athanasoglou et al. 2008; Brissimis et al. 2008). ${ }^{12}$ Similar evidence arises in Bourke (1989) for banks in Europe, N. America and Australia. For Chinese banks, Garcia-Herrero et al. (2009) report a significant positive link between performance and the ratio of equity to assets. A significant positive relation between income and capital structure also emerges in Haron's (1996) analysis of Islamic banks. We extend this interface for Fintech entities. Accordingly, and for both bank and Fintech entities, Hypothesis 3 states that,

H3 (B \& F): Performance (both prudential and financial) has negative association with capital risk, i.e., a positive link exists between capital levels and performance.

Footnote 10 (continued)

Negative associations are also apparent for banks in emerging markets (Zhang et al. 2013). Additionally, NPLs are an increasing function of inefficiency in Japanese banks (Altunbas et al. 2000).

11 As a guide to best-practice in liquidity management, the Basel Committee on Banking Supervision established the Working Group on Liquidity (December 2006). The Working Group addresses liquidity risk management in member countries (Basel Committee on Banking Supervision, 2008).

12 Studies of European banks (Athanasoglou et al. 2006, 2008; Brissimis et al. 2008; Molyneux and Thonton, 1992; and Pasiouras and Kosmidou 2007) also identify a significant positive capital-performance link. 
Operational risk is another major risk element. The Basel Committee on Banking Supervision (2011) regards it as: "risk of loss ... from inadequate ... internal processes, people, and systems ... external events." (Page 3). ${ }^{13}$

Several studies report a negative relation between performance and operational risk. Cummins et al. (2006) reveal significant negative stock price reactions to the announcement of operational losses in US financial institutions. Sun and Chang (2011) characterize operational risk in relation to the volatility of bank performance. Negative stock price reactions to the first press announcement of operational losses are also evident in Sturm's (2013) examination of European banks. McNulty and Akhigbe (2017) employ legal expenses as a proxy for weak internal controls. They find legal expenses to be increasing in loan losses, but decreasing in stock returns and ROA.

The above studies principally address pre-Fintech era conditions. The transition into digital services has caused appreciable growth in Chinese banks' IT expenses (Lee 2019). It is therefore an empirical question as to whether the inverse relation between operational risk and performance persists. In respect to bank and Fintech entities, Hypothesis 4 assumes such a link remains.

H4 (B \& F): Performance (both prudential and financial) has negative association with operational risk.

Marker risk features as a further important determinant of bank performance. ${ }^{14}$

Sun and Chang (2011) capture market risk in terms of the standard deviation of exchange rate and interest rate movements. They report a positive correlation between bank efficiency and exchange rate volatility in the context of emerging Asian markets. However, the precise relation between market risk and bank performance hinges on the choice of market risk proxy as well as study context and period. For example, results in Zhang et al. (2013), for BRIC economies, suggest an inverse association between market risk and bank performance. They capture market risk in relation to the proportion of a bank's borrowings through the inter-bank market (p. 152).

\footnotetext{
${ }^{13}$ Because of its broad sweep, operational risk is not as tightly defined as credit risk. Nonetheless, operational weakness can occasion major loss (Chernobai et al., 2011). For in-depth definition and measurement of operational risk, see Netter and Poulsen (2003). Moosa (2007) characterizes operational risk loss in terms of cause, type of event, and legal and accounting costs. Studies of operational risk include Chernobai et al. (2011), Sturm (2013), Sun \& Chang (2011), Barakat \& Hussainey (2013), and McNulty \& Akhigbe (2017).

${ }^{14}$ Reputational risk is distinct from operational risk. Part 30.29 of the Basel Committee on Banking Supervision (2019a) offers concise definition of reputational risk. According to Walter (2016), share prices, rather than financial returns, more adequately reflect reputational risk losses. As stakeholder interests widen, reputational risk naturally becomes more pertinent, especially in relation to firm value (Gatzert, 2015). Management of reputational risk is therefore a strategy issue (Mukherjee et al, 2015). Furthermore, and as highlighted in Fiordelisi et al. (2013), reputational risks are increasing in corporate profit and size, but decreasing in capital and intangible assets. Perry and De Fontnouvelle (2005) measure reputational loss in relation to a firm's stock price reaction to announcement of serious operational failings. In relation to corporate misconduct, Murphy et al. (2009) reveal allegations of fraud undermine stock values more than purported bribery, copyright or patent infringements. Reputational losses may also be increasing in leverage (Karpoff et al. 2008; Sturm 2013). For important survey analyses and insights on reputational losses, see Walter (2007) and Gatzert (2015). In the present study, the proxy we use for reputation risk has high correlation with some important explanatory variables. Accordingly, we capture reputation risk as an embedded effect within one or more control variables.
} 
The empirical evidence on the link between market risk and bank performance is unequivocal. We form a joint hypothesis. First, lenders with more growth options experience stronger returns. Second, such lenders are subject to greater value-at-risk (in relation to external market shocks). Accordingly, Hypothesis 5 asserts, in respect to both Chinese banks and Fintech providers that,

H5 (B \& F): Performance (both prudential and financial) has positive association with market risk.

Our next two hypotheses are specific to the Fintech trends enveloping China. Leading studies on Chinese bank performance largely relate to the pre-Fintech era (García-Herrero et al. 2009; Sun and Chang 2011; Tan and Floros 2013; Zhang et al. 2013; Li and Wang 2015; and Tan 2016). The literature on Fintech is emerging. Recent highlights in this domain include Chishti and Barberis (2016), Cumming and Schwienbacher (2018), Haddad and Hornuf (2018) and Wang et al. (2020).

The academic literature offers even less coverage of the impact of Fintech on banks' corporate policies. Traditional banks in the digitalization era face significant pressure to upgrade and invest in Fintech. Such investment places considerable pressure on working capital. Declining dividend payouts likely characterize banks' adaptation to Fintech. Banks that reinvest more of their earnings are thus more likely to retain market share. Accordingly, Hypothesis 6a asserts,

H6a (B): For Chinese banks, an inverse relation exists between prior year dividend pay-out and current year profitability

As a counter argument to Hypothesis 6a, the signaling literature (Lintner 1956; and Charest 1978) suggests that weakening pay-outs foreshadow cash flow or liquidity tightening. ${ }^{15}$ A range of studies report adverse stock price reactions to dividend cuts and/or omissions (see, for example, Aharony and Swary 1980; Benesh et al. 1984; and Michaely et al. 1995). In such a context, declining or low pay-outs signal deteriorating firm prospects. However, investor perceptions on dividends may have evolved alongside Fintech. Bank shareholders may recognize the importance of dividend restraint in opening-up access to new technologies and growth option stories.

For digital financial service providers, reinvestment pressures may be even greater. Tech and internet firms' strong working capital and cash needs dictate the reinvestment of most, if not all, earnings. Accordingly, little variation in dividend payout is likely across the Fintech sector. Moreover, for the minority of Fintech entities that do pay substantial dividends, the likelihood is that many of them already have strong performance records. Based on the foregoing, we posit in Hypothesis $6 \mathrm{~b}$ that Fintech performance is largely invariant to dividend payout.

\footnotetext{
${ }^{15}$ Such an information effect runs counter to Miller and Modigliani [or MM (1961)] where perfect markets and exogenous investment policies preclude a dividend signaling role. Watts (1973) offers some support for the MM (1961) dividend "irrelevance" result in his analysis of dividend changes and abnormal stock returns,
} 
H6b (F): Given investor demands for reinvestment of earnings, there is minimal variation in Fintech entities' dividend payout ratios. Current year profitability is therefore invariant to prior year dividend pay-out.

This study's next hypothesis addresses the swathe of exchange listings in Chinese banks during the last 15-20 years. Prior to 2005, only a small number of Chinese banks had an exchange listing. Many of China's leading lenders cemented exchange-traded presence with onshore A- and/or offshore H-share listings (McGuinness and Keasey 2010) in the period 2005-10. State-based directives to internationalize and bolster equity capital underlie this development.

The seasoning period of a bank's stock has potential impact on profitability. This applies to banks issuers with a single A- or H-share listing, as well as to those with cross-listings of the two. The central proposition is that IPO launch is more likely when bank fundamentals and market sentiment are strongly positive. Issuers and their advisors thus seize on "windows of opportunity" (Loughran and Ritter 1995) or "exuberant expectations" pertaining to future performance (Ljunqvist et al. 2006). As a consequence, IPO firms likely experience declining stock (Ritter 1991) and financial returns (Jain and Kini 1994) in the years following IPO completion. We posit in Hypothesis 7 that such effects are relevant to both traditional Chinese banks and online lenders.

H7 (B \& F): Performance (both prudential and financial) declines with time since IPO.

Chinese banks are subject to major reorganization in the run-up to IPO. ${ }^{16}$ Lenders typically sell-off underperforming assets, re-capitalize, and clean-up balance sheets. The whole process causes an appreciable drop in NPLs. In the years thereafter, investors face the risk that NPL rates gradually revert to pre-listing levels. Such risk underlies Hypothesis 7. The opposite applies if a bank's reorganization and IPO infuse it with a more commercial orientation.

The literature on discretionary accruals and earnings management informs Hypothesis 7. Relevant studies suggest surging profits pre-IPO with remedial declines thereafter (Aharony et al. 2000; Teoh et al. 1998; and DuCharme et al. 2001). ${ }^{17}$ Even in the absence of earnings management, rising pre-IPO earnings may fuel unrealistic investor expectations (Jain and Kini 1994).

As a counter argument to the above, Chinese banks, as highly visible issuers, face forensic-level scrutiny from regulators, policy-makers, analysts, intermediaries, investors, and others. Banks therefore face intense pressure to demonstrate earnings quality. Developments in China's regulatory, disclosure and accounting standards also lessen the scope for accrual and earnings management activities (Chen and Zhang 2014). The age of founders and incumbent senior officials inevitably rises with time since IPO. As Johnson et al (2013, p. 238) reveal in their assessment of management demographics, older top-management teams confer an experience advantage but tend to suffer from greater inertia and risk aversion. Older management teams and firms may be less able to manage and implement strategic change (Wiersema and Bantel 1992). Such risk aversion may render older banks more

\footnotetext{
16 McGuinness \& Keasey (2010) offer discussion on such reorganizations in respect to China's leading banks.

17 However, Ball and Shivakumar (2008), for UK and US IPOs, find many issuers list on conservative earnings.
} 
susceptible to Fintech disruption. In empirical terms, Talavera et al. (2018) report a positive association between NPLs and bank age. More generally, Balasubramanian and Lee (2008) detect an inverse association between firm age and innovation. In the present context, younger, newly-listed banks' greater adaptability and ability to embrace Fintech suggests a further strand of support for Hypothesis 7. Younger banks are therefore more likely to outperform older, more-entrenched lenders during the era of digitalization.

Our next two hypotheses address issues particular to incumbent banks. Hypothesis 8 below asserts that a Chinese bank's access to and deployment of Fintech proficiencies benefits from joint ventures and other business tie-ups with strategic foreign bank lenders. In empirical terms, Luong et al (2017) demonstrate that foreign institutional ownership boosts innovation. They offer "knowledge spillovers" as one of the reasons for such an outcome. Foreign investors also add resource channels and networks to the investee firm. From the investor's perspective, the equity holdings garnered invite "springboard" advantage (Luo and Tung 2007). We extend these accounts by considering the effects of foreign strategic holdings on bank performance during the recent period of digitalization. Accordingly, Hypothesis 8 contends that foreign equity ownership, by extending the reach of Chinese lenders to Fintech, promotes stronger performance.

H8 (B): During the recent era of digitalization, stronger prudential and financial performance arose in banks with strategic foreign equity owners.

Although restricted in scale by Foreign Investment Law (Thomson Reuters 2020), offshore lenders' minority ownership stakes may contribute to stronger Chinese bank performance. For instance, Cheng et al. (2016) indicate that foreign strategic investors improve risk management in non-state-owned Chinese banks. Contraction in foreign bank loans in China in the post Global Financial Crisis period (Fenech et al. 2014) also underscores the growing importance of tie-ups with domestic bank partners.

Support for Hypothesis 8 may not arise if the principal motivation for the foreign strategic investor is the cultivation of political connections with wider industry and regulatory players. ${ }^{18}$ The offshore investor may even countenance losses on its equity position if it gains more broadly; specifically, in terms of brokering licensing and other business tie-ups.

Our final research question addresses the effect of state ownership on bank performance. A priori, the sign of any such association is unclear. For example, García-Herrero et al. (2009) report weaker performance in Chinese state-owned commercial banks. In contrast, and perhaps reflective of a more competitive and contestable environment in the years since, Tan (2016) reports stronger performance in state-run banks relative to joint-stock commercial and city lenders.

State-owned Chinese banks likely benefit from re-capitalization, licensing and market approval advantages as well as greater access to state-approved technologies. Such advantage should be most visible in China's six largest Commercial Banks. Positive, but weaker effects, may also arise for China's nine Joint Stock Commercial Banks (see page 1 of EY 2019a for a list of such entities). Additionally, Cheng and Qu (2020) reveal, that among Chinese banks, state lenders have been quicker to invest in Fintech. Accordingly,

\footnotetext{
${ }^{18}$ Liu et al. (2014) demonstrate foreign funds' preference for investment in state-owned Chinese listed entities.
} 
SOE banks may be in a stronger position to stave-off Fintech disruption and to exploit the growth options arising from it. Hypothesis 9 thus avers that,

H9 (B): During the recent era of digitalization, state-controlled banks registered stronger prudential and financial performance than non-state-owned lenders.

As a counter argument, profitability in state-owned banks may weaken if central and local government owners induce agency problems. SOE's "soft budget constraints" (Megginson et al. 2014) accentuate such concerns. The political priorities of the government stakeholder also matter. Provincial, rather than central government owners, are present in some of China's smaller banks. For such banks, social and community-based responsibilities often require the investee bank to support employment targets by lending to local enterprises on non-commercial grounds. ${ }^{19}$ The Chinese state's role as a champion of ESG (McGuinness et al. 2017; Sam and Zhang 2020) is also important. Pressure on state-controlled banks to fund such activities may crimp short-run returns, despite the longer-term benefits to bank competitiveness from such lending.

\subsubsection{Control effects}

Moderation or mediation of the main effects proposed in Hypotheses 1-9 may arise from firm- and market-specific factors. Bank size is important. Due to economies of scale, large banks should have a cost or profitability advantage. The "too-big-to-fail" argument (Goddard et al. 2004b; Iannotta et al. 2007) also protects larger banks' market share and core income. In empirical terms, bank survival rates strongly relate to asset size (Stiglitz 1972; Psillaki et al. 2010).

A wide range of diversification opportunities enable large banks to bolster returns and reduce risks (Garcia-Herrero et al. 2009). As argued in Haslem (1968), large banks' lower capital ratios also offer advantage in terms of income generation. Large firms also benefit from more flexible organizational and financial structures and have greater access to new capital during crises (Psillaki et al. 2010). For Chinese banks, size also couples with strategic political importance. The state naturally confers resource and market access advantage on China's largest banks (Garcia-Herrero et al. 2009).

As counter arguments, large banks may be more difficult to manage. Managers' selection of growth over profits may also enable an inverse size-performance association (Eichengreen and Gibson 2001). Advances in bank technology and productivity also weaken scale economy advantages (Athanasoglou et al. 2006). This argument has particular resonance in the Fintech era.

Empirical evidence on the size-profitability relation is mixed. For European banks, both Athanasoglou et al. (2006) and Iannotta et al. (2007) identify significant positive associations. In contrast, Smirlock (1985) documents a significant negative size-performance link for US banks. Furthermore, Athanasoglou et al. (2008) and Pasiouras and Kosmidou (2007) report a negative but insignificant relation for respective EU and Greek bank samples. For Chinese banks, Tan (2016) identifies an inverse size-profitability link. A non-linear relation

\footnotetext{
19 Apart from corporate SOEs, the principal government-based investors in China's leading banks are (1) the Ministry of Finance, (2) Huijin, (3) the China Securities Finance Corporation, (4) the National Social Security fund, (5) provincial or city-based SOEs, (6) finance bureaus, and (7) provincial governments.
} 
is also possible (see, for example, Haslem 1968; McAllister and McManus 1993; and Eichengreen and Gibson 2001).

Other internal variables commonly employed in the assessment of bank performance include market-book ratios (McNulty and Akhigbe 2017) and staff expenses (Eichengreen and Gibson 2001; Molyneux and Thornton 1992). With regard to external determinants, various studies emphasize market concentration (Bourke 1989; Molyneux and Thornton 1992; Saona 2016) and ownership characteristics. ${ }^{20}$ Inflation $^{21}$ and other macroeconomic effects also commonly feature. A number of analyses also control for interest rates (Athanasoglou et al. 2008; Bourke 1989; Brissimis et al. 2008; Molyneux and Thornton 1992), GDP growth rates (Phan et al. 2019; Saona 2016), as well as changes in economic activity (Brissimis et al. 2008).

\section{Data and methodology}

\subsection{Data}

This study's dataset covers annual end-of-year data for China's leading exchange-listed banks for the seven-year period, 2013 to 2019. For this purpose, we scrutinize 40 Chinese banks. Among this number, six are state-owned commercial banks (SBs), nine national joint-stock commercial banks (JSCBs), 22 city commercial banks (CCBs), and three rural commercial banks (RCBs). According to Ernst \& Young, China (2019), there were 47 exchange-listed banks as of the 2018 year-end. The respective numbers for SBs, JSCBs, CCBs and RCBs were 6, 9, 22 and 10. Accordingly our data sample includes all exchangelisted SBs, JSCBs and CCBs. However, we only include three of the 10 listed RCBs. The three selected are the predominant sector entities, accounting for more than 50 percent of listed RCBs' assets, net profits and operating income (EY 2020). The selected RCBs are thus the leading players in the sector.

The majority of exchange-listed Chinese banks did IPO prior to 2013. However, a minority listed during China's Fintech era, 2013-2019. The absence of market data for such banks for the initial years of this sample period dictates the use of an unbalanced panel.

We also collected annual report data on 25 Chinese exchange-listed Fintech firms for the same period of interest, 2013-19. Table 11 indicates the companies' websites and their place and date of stock exchange listing. All 25 control group firms offer a significant element of credit-based activity in their business models. Such firms principally operate in mainland China, run a substantial part of their business in bank or credit-related services and have at least three years of available book and market data. Four of the 25 issuers are listed on HKEX, with the remainder present on the NYSE $(n=10)$, NASDAQ $(n=10)$ and Shanghai Stock Exchange $(n=1)$ markets. We initially considered 27 exchange-listed Fintech entities. However, two (Xiongmaojinkong, as listed on HKEX, and Dianniu, as traded on NASDAQ) had to terminate business activities. Accordingly, we exclude both

\footnotetext{
20 See Bourke (1989), Molyneux and Thornton (1992), Altunbas et al. (2001), Athanasoglou et al. (2008), Brissimis et al. (2008), Lensink et al. (2008), Saona (2016), Tan (2016), and Shaban and James (2017).

21 See Bourke (1989), Molyneux and Thornton (1992), Demirguc-Kunt and Huizinga (2000), Athanasoglou et al. (2006, 2008), Pasiouras and Kosmidou (2007), Saona (2016), Tan (2016) and Phan et al. (2019).
} 
companies from our final control sample. Most Fintech entities in China have unlisted status. This characteristic extends to leading unicorns like Ant Financial.

The opening year for main and control samples reflects major development of internet and digital finance in China in the period from 2013 onwards. In particular, Zhou et al. (2015), in their analysis of China's financial reforms between 1978 and 2015, identify four principal phases. In their analysis, the fourth stage, which began in the watershed year of 2013, characterizes regulatory reforms on surging digital finance and related internet services. $^{22}$ Shen and Huang (2016, p. 221) argue that Chinese investors regard Alipay's launch of online sales in collective investment funds in mid-2013 as the catalyst for China's surging digital finance market.

The data source relevant to financial and market information on traditional banks is CSMAR. Additionally, data sources at the World Bank (https://data.worldbank.org/indic ator/FB.BNK.CAPA.ZS?locations=CN), OECD (https://data.oecd.org/china-people-srepublic-of.htm) and PBOC (http://www.pbc.gov.cn/diaochatongjisi/116219/116319/37502 74/index.html) serve in relation to information on industry-specific and macroeconomic variables. Finally, for data specific to Chinese Fintech entities' industry and macroeconomic characteristics, we utilize KPMG sources (https://home.kpmg/cn/zh/home/campa igns/2019/12/china-fintech-50.html; _ https://home.kpmg/xx/en/home/industries/financialservices/pulse-of-fintech.html) and the China Fintech Enterprise database (http://www. fintechdb.cn).

\subsection{Variable selection}

\subsubsection{Dependent variables}

As guided by prior studies on bank performance (see, among others, Athanasoglou et al. 2008; Garcia-Herrero et al. 2009; Bailey et al. 2011; Dietrich and Wanzenried 2011; Aebi et al. 2012; Tan 2016; and Phan et al. 2019), we address financial performance using ROA and ROE measures. ROA is the ratio of pre-tax profits to total assets and $R O E$ the ratio of net income to total equity.

We also examine Chinese listed banks' prudential performance. We consider this issue in relation to two variables. The first one is the non-performing loan (NPL) rate. The China Banking and Insurance Regulatory Commission (CBIRC) imposes guidelines and audits NPL positions. ${ }^{23}$ The achievement of NPL rates below market norms signals prudential success. However, adjustment of NPL rates may arise through the sale of underperforming loans to asset-management companies. To at least partially control for this issue, we consider the proportion of a lender's loan book categorized as "Special Mention". Although CBIRC regards such advances as performing loans, the label forewarns investors of possible future concerns. Variable SML, the proportion of a lender's loan assets classified as Special Mention, is our second measure of prudential performance.

An SML focus is important for two reasons. First, Special Mention loans are not normally available for possible sale. Second, current year loan loss provisions do not relate to

\footnotetext{
22 See Page 31, and specifically Note 18, of Zhou et al. (2015).

${ }^{23}$ For discussion of the definition and application of the CBIRC's five-tier loan classification system, see the Huishang Bank Corporation Limited Annual Report 2018 (Pages 274-274). Within the five-tier system, the upper two categories, of "Pass" and "Special Mention" signify preforming loans. The lower three tiers, of "Substandard", "Doubtful" and "Loss", signify non-performing loans.
} 
advances in the "Special Mention" category. However, rising loan loss provisions may be a harbinger of future losses on performing loans currently classified as SMLs.

For China's Fintech entities, the regulatory structure governing NPLs and SMLs is still developing. Neither the CBIRC nor PBOC regulates online micro-lending Fintech entities directly (Fitchratings 2020). Instead, supervision falls within the remit of "local financial regulatory offices" (Akin Gump 2020). Nonetheless, reforms proposed by China's central bank regulators suggest that more stringent leverage and capital requirements are likely (Akin Gump 2020). An existing regulatory framework applies in China for crowdfunding (BIS 2020, pp. 17-18).

Figure 1 depicts general trends in each of the four dependent variable measures, ROA, ROE, NPL and SML, for each study year (2013-2019) and bank sector (SB, JSCB, CCB and $\mathrm{RCB})$.

\subsubsection{Explanatory variables: active effects relevant to Hypotheses 1-9}

For Hypotheses 1-5, we construct variables for credit, liquidity, capital, operational, and market-based risks. As guided by the literature (Athanasoglou et al. 2008; Brissimis et al. 2008; Iannotta et al. 2007; Tan and Floros 2013; Tan 2016; and Phan et al. 2019), we measure credit risk as the ratio of loan loss provisions to total loans (LLP). Loan loss provisions are an expense. They capture current period losses arising from defaults, delays in interest payments, and related legal and follow-up charges. Accordingly, variable LLP offers an indicator of movement in NPL rates. As highlighted earlier, NPL rates relate to aggregate loan position. Moreover, there is no mechanical linkage between variables LLP and NPL. However, the correlation between them is likely to be positive. For this study's traditional bank group, such correlation is +0.199 (see Table 15).

As informed by Bourke (1989) and Brissimis et al. (2008), liquidity risk is the ratio of liquid assets to total assets (LQ). In the spirit of Berger and DeYoung (1997), Athanasoglou et al. (2008), Brissimis et al. (2008), Garcia-Herrero et al. (2009), Fiordelisi et al. (2011), Tan (2016), and Phan et al. (2019), we measure capital risk as the ratio of total equity to total assets (EA).

The ratio of operating costs in period t to $\mathrm{t}-1(\mathrm{Ct} / \mathrm{Ct}-1)$ serves in capturing operational risk. The ratio of non-interest operating costs to bank revenue figures in other studies (Dietrich and Wanzenried 2011; Saona 2016; McNulty and Akhigbe 2017; Phan et al. 2019). Such a construction controls for a bank's technical efficiency (Agoraki et al. 2011). Our fifth risk measure, VaR, captures a bank's value-at-risk (Frey and McNeil 2002; and Kerkhof et al. 2010). Chinese banks provide daily VaR values (at a 99\% confidence level, based on daily returns for 250 days of historical market data). We employ VaR end-of-day values as based on year-end annual reports.

LLP, LQ, EA, $\mathrm{C}_{\mathrm{t}} / \mathrm{C}_{\mathrm{t}-1}$ and VaR are the active arguments for Hypotheses 1-5. A lender's prior year-end dividend payout ratio $\left(\mathrm{DPOR}_{\mathrm{t}-1}\right)$ is the active variable for Hypothesis 6 . The active effect for Hypothesis 7 is the time since listing [TimeList $=\mathrm{Ln}(1+$ time in months since IPO)]. Some of China's leading banks have cross-listings in separate blocks of nonfungible A- and H- stock, in which the Shanghai or Shenzhen Stock Exchange (HKEX) hosts the A-share (H-share) IPO. In such cases, TimeList is the time since the most recent of the two exchange listings. 


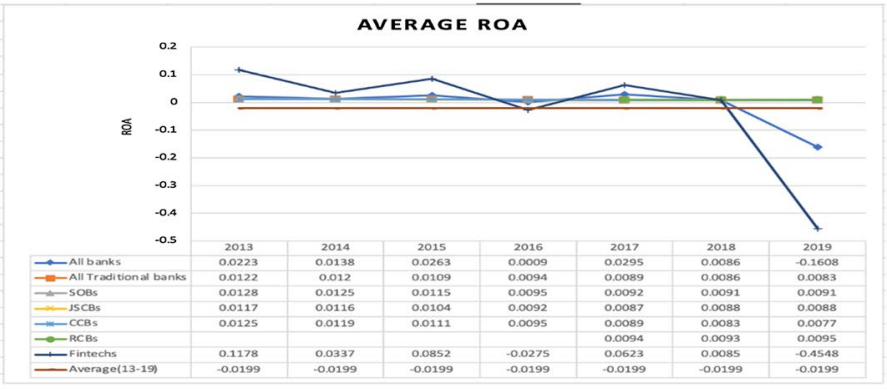

(a)

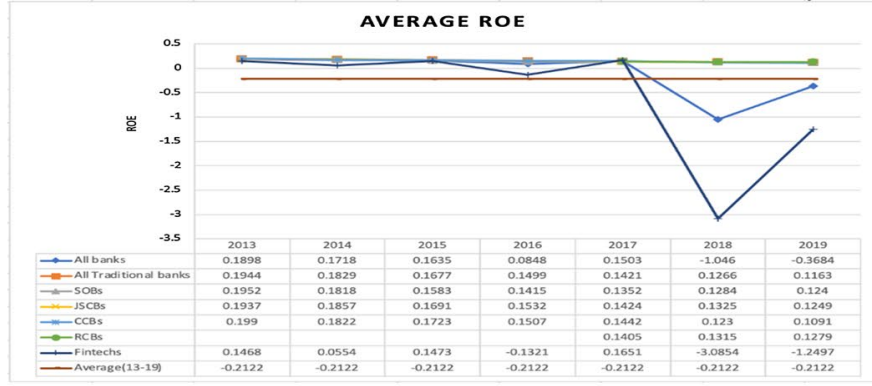

(b)

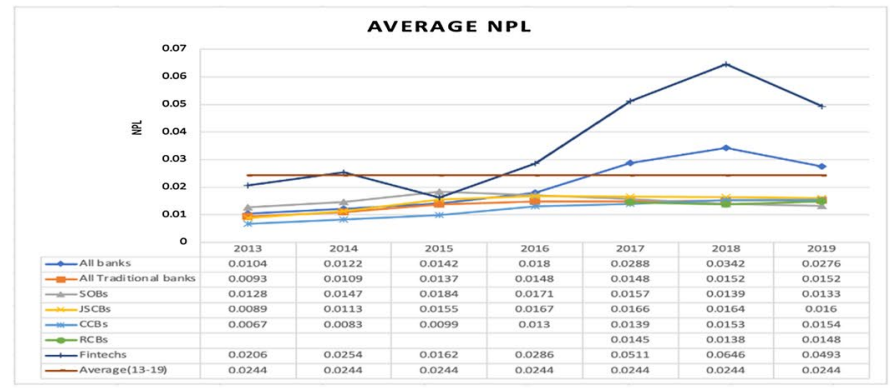

(c)

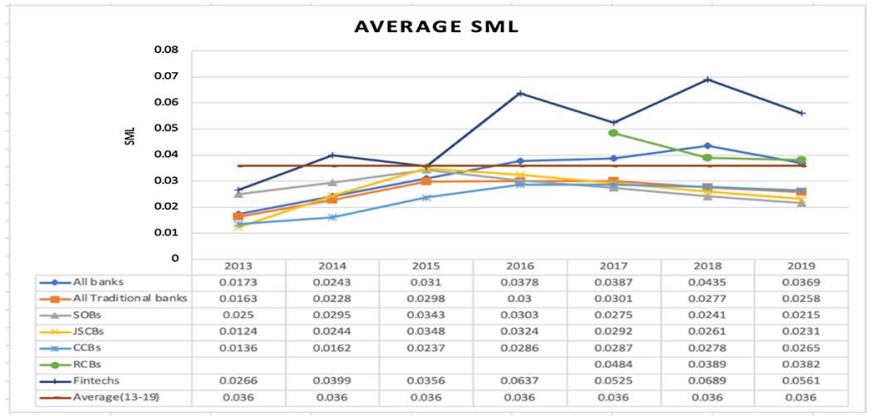

(d)

Fig. 1 ROE, ROE, NPL \& SML trends over the 2013-2019 study period. Note: Rural commercial bank data were available from 2017 only

A dummy for the presence of one or more foreign strategic owners (ForStr) functions 
in relation to Hypothesis $8 .^{24}$ Hypothesis 9 asserts that bank performance is increasing in state ownership. For this purpose, dummies SB, JSCB and CCB feature. For a state-owned commercial bank, $\mathrm{SB}=1$. For a joint-stock commercial bank, JSCB $=1$. A value of one for CCB identifies a City Commercial Bank. The omitted dummy effect is for Rural Commercial Banks (RCB). ${ }^{25}$

\subsubsection{Control variables}

We also consider a number of other bank specific characteristics. As informed by McNulty and Akhigbe (2017), the present inquiry utilizes a bank's market-to-book (MB) ratio to capture growth potential. Regressions also control for bank size, S. Congruent with the literature (Altunbas et al. 2007; Athanasoglou et al. 2006, 2008; Iannotta et al. 2007; Psillaki et al. 2010; Fiordelisi et al. 2011; Barakat and Hussainey 2013; Laeven et al. 2016; Saona 2016), bank size is the natural logarithm of total assets. As highlighted in McNulty and Akhigbe (2017), inclusion of Market-to-book and firm size variables controls for two of the three factors in Fama and French (1993).

Regressions also control for industry and market effects. In line with Phan et al. (2019), variable FinTech ${ }_{t}$ captures the number of Fintech firms in a given year. As guided by Tan and Floros (2013, p. 384), we measure equity market maturity via total market capitalization/GDP.

We also address macroeconomic effects. As in Tan (2016), regressions control for changes in China's Consumer Price Index (INF). Other studies also control for total investment/GDP (Brissimis et al. 2008) and GDP growth (Agoraki et al. 2011; Saona 2016; Tan 2016; and Phan et al. 2019). We exclude consideration of GDP growth given its high correlation with one or more other explanatory variables within our model design.

Additionally, bank profitability increases as the spread between long- and short-term interest rates widens (Athanasoglou et al. Li and Wang (2015) and Kohlscheen et al. 2018). In capturing this effect, we take the spread between ten-year government bond yields and 3-month inter-bank rates (LIR-SIR). Such a spread proxies for a bank's net interest margin. We also control for China's average Reserve Ratio Requirement (RRR). As reported in Chang et al. (2019), an increase in the RRR constrains SOE funding. High and rising RRR levels are more common at times of strong economic growth and bank profitability.

Table 1 offers summary of all variables in the foregoing.

\subsection{Model \& methodology}

In light of differences in the regulatory environment surrounding traditional banks and internet finance companies in China (Mingkang 2015), we assess each group separately.

We construct the following regression model for the determinants of bank performance:

\footnotetext{
${ }^{24}$ Strategic parties are foreign banks and/or overseas sovereign fund investors with one percent or more of a Chinese bank's equity. Temasek and HSBC in CCB and BoCOM serve as prominent examples. See McGuinness and Keasey (2010) for wider discussion of foreign bank ownership in Chinese lenders.

25 Tan's (2016) analysis addresses JSCBs and CCBs, with the dummy for China's leading state-owned banks the omitted sector in regressions. Several studies (Bourke 1989; Molyneux and Thornton 1992; Altunbas et al. 2001; Athanasoglou et al. 2008; Brissimis et al. 2008; Lensink et al. 2008; Saona 2016; Tan 2016; Shaban and James, 2017) consider state ownership as an explanatory effect for bank performance.
} 


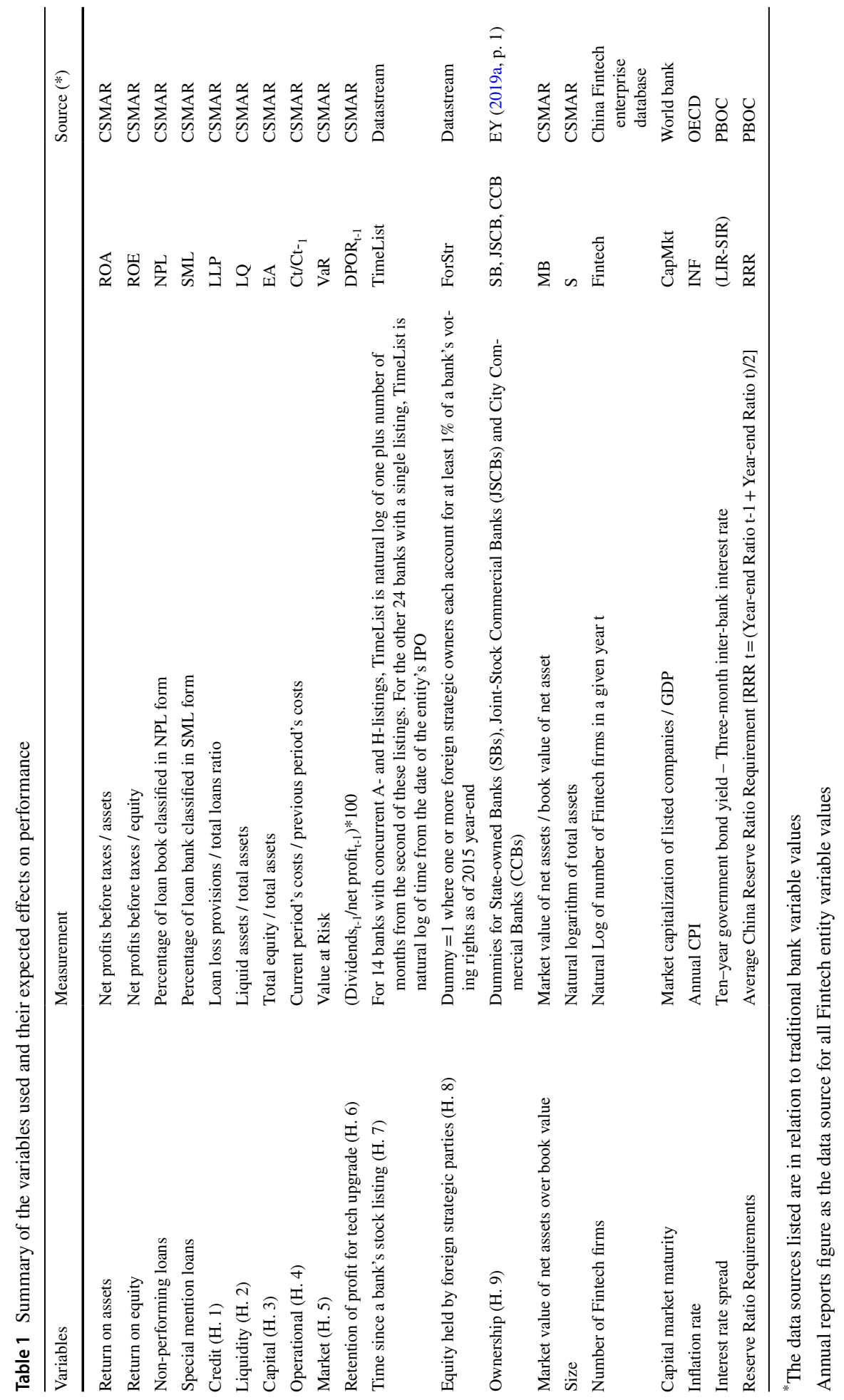




$$
\begin{aligned}
& \text { Performance }_{i t}=\beta_{0}+\beta_{1} L L P_{i t}+\beta_{2} L Q_{i t}+\beta_{3} E A_{i t}+\beta_{4} C_{i t} / C_{i t-1}+\beta_{5} V a R_{i t} \\
& +\beta_{6} \text { DPOR }_{i t-1}+\beta_{7} \text { ForStr }_{i t}+\beta_{8} S B_{i}+\beta_{9} J S C B_{i}+\beta_{10} C C B_{i} \\
& +\beta_{11} \operatorname{Ln}(1+\text { TimeList })_{i t}+\beta_{12} M B_{i t}+\beta_{13} S_{i t}+\beta_{14} \text { FinTech }_{t} \\
& +\beta_{15} \text { CapMkt }_{t}+\beta_{16} A v R R R_{t}+\beta_{17} I N F_{t}+\beta_{18}(L I R-S I R)_{t}+u_{i t}
\end{aligned}
$$

Four different performance measures feature: ROA, ROE, NPL; \& SML.

NPL and SML are respective percentages for "Non-Performing" and "Special Mention" loans.

Explanatory effects: LLP (Loan loss provisions/total loans); LQ (Liquid assets/total assets); EA (Total equity/total assets); $\mathrm{Ct} / \mathrm{Ct}^{-}{ }_{1}$ (Current period's running costs/previous period's running costs); VaR (Value-at-Risk); $\mathrm{DPOR}_{\mathrm{t}-1}$ (Dividends $_{\mathrm{t}-1} /$ net profit $\left._{\mathrm{t}-1}\right) * 100$; ForStr (Dummy for one or more foreign strategic owners); SB (Dummy for State-owned Banks); JSCB (Dummy for Joint-Stock Commercial Banks); CCB (Dummy for City Commercial Banks); TimeList (Time since IPO); MB (Market to book of net assets; S (Log of total assets); Fintech (Log of number of Fintech firms); CapMkt (Market cap of listed companies/GDP); RRR (Reserve Ratio Requirement \%); INF (Inflation rate); and LIR-SIR (Long-short term interest rate). Table 1 offers further details on variable construction.

In a first stage of analysis, we adopt a static model approach. Prior studies investigating static relationships often employ fixed or random effects models (see, for example, Athanasoglou et al. 2006; Pasiouras and Kosmidou 2007). Based on Hausman test results, we opt for a fixed rather than random effects estimation method.

We deploy system Generalized Method of Moments (GMM) estimators in our dynamic modelling approach. GMM estimation not only serves in remedying biases and inconsistencies, it also controls for "profit persistence" (Athanasoglou et al. 2008; and Tan, 2106). As reported in Tan's (2016, p. 88) overview of 13 leading studies on bank performance, GMM is by far the dominant approach. We employ a one-step rather than a two-step GMM estimation approach. As argued in Judson and Owen (1999), one-step estimators are generally less biased. Additionally, the one-step approach features in a number of analyses of bank performance. Examples include Athanasoglou et al. (2008) and Tan (2016). ${ }^{26}$

Following Tan's (2016) examination of the determinants of Chinese bank profitability, capital risk (EA) and loan loss provisions (LLP) serve as the respective endogenous and predetermined arguments. In accordance with Athanasoglou et al. (2008), we run our model twice: First, with EA and LLP assumed exogenous; and second with EA as endogenous and LLP predetermined. The relevant p-value for the Sargan test for the first run is 0.000 , suggesting over-identification. In the second run, the p-value is 1.000 , indicating acceptable instruments. Moreover, test results conducted on other variables suggest LLP is the appropriate predetermined variable. Based on a Sargan (1958) over-identification test (1 period lag), with application to GMM (Hansen 1982), we also confirm other variables are largely free of endogeneity concerns.

Additionally, and in-line with Maddala and Wu (1999), we check for panel stationarity via the Fisher (1932) test. This test supposes a null hypothesis of non-stationary data with unit root. Results in Appendix 1 indicate rejection of the null hypothesis at the 1\% level for all bank-specific variables, with the exception of variable $\mathrm{S}$ in the case of traditional banks, for which the null hypothesis is rejected at the $10 \%$ level. We retain S given its stationarity

26 See Judson and Owen (1999) for detailed discussion of one- and two-step GMM designs. 
at the 10\% level. Finally, an Arellano-Bond (1991) test confirms the absence of second order auto-correlation.

For the separate group of Fintech entities, we estimate the following regression model:

$$
\begin{aligned}
\text { Performance }_{i t}= & \beta_{0}+\beta_{1} L_{L P}+\beta_{2} L Q_{i t}+\beta_{3} E_{i t}+\beta_{4} C_{i t} / C_{i t-1}+\beta_{5} V_{a R_{i t}} \\
& +\beta_{6} \text { DPOR }_{i t-1}+\beta_{7} L n\left(1+\text { TimeList }_{i t}+\beta_{8} M B_{i t}+\beta_{9} S_{i t}\right. \\
& +\beta_{10} \text { FinTech }_{t}+\beta_{11} \text { CapMkt }_{t}+\beta_{12} \text { AvRRR } \\
& +\beta_{13} I N F_{t} \\
& +\beta_{14}\left(\text { LIR }_{t}-\text { SIR }\right)_{t}+u_{i t}
\end{aligned}
$$

Equation 2 above naturally excludes variables that have a configuration specific to traditional banks, namely SB, JSCB, CCB and ForStr. For reasons of comparison, we retain all other explanatory variables present in Eq. 1, for the analysis of Fintech entities, in Eq. 2.

For reasons of consistency, we also estimate the above model in two stages. First, through a fixed-effects approach and, second, in a dynamic setting utilizing a GMM design. Appendix 1 reports relevant Fisher (1932) test results in relation to the stationarity of the Fintech panel.

\section{Empirical results}

\subsection{General trends in the performance of Chinese Fintech entities and banks: 2013-19}

Figure 1 reveals a significant decline in Fintech profitability over the 2013-2019 study frame. At the open of the period, Fintech entities' ROA levels were stronger than those for traditional banks. By 2019 the situation had reversed. Through their engagement in riskier activities (P2P lending, for example), and the low regulatory compliance costs imposed on virtual banks during the early years of the sample period, Fintech entities initially outperformed traditional banks. However, by sample period end, Fintech lenders registered adverse ROA and ROE numbers (of -0.46 and -3.09), and major credit losses (with NPL and SML ratios of $4.93 \%$ and $5.61 \%$ ).

Partially due to Fintech competition, ROA levels also declined for traditional banks over the period (see Fig. 1a). Within the traditional bank group, state-owned banks achieved the highest ROA. Nonetheless, all traditional bank sectors were subject to a declining ROA trend before stabilizing in 2017/8. ROE numbers also highlight a negative trend (see Fig. 1b). Due to Fintech entities' strong equity issuance (Caixin 2020), traditional banks outperformed in ROE terms. Within the latter group, joint-stock commercial banks achieved the highest ROE levels.

Figure 1c reveals a steady upturn in NPLs in all traditional bank sectors during the course of the seven-year study period. Fintech entities experienced much greater variation in NPL rates, with a marked increase evident between 2015 and 2018. Figure 1d highlights SML trends. A steady initial increase is evident for traditional banks between 2013 and 2015 with indications of stabilization and improvement in the years thereafter. In contrast, Fintech entities experienced strong and volatile SML increases over the period. As today's SMLs may become tomorrow's NPLs, such trends sound a cautionary note on Fintech entities' rising credit risks.

The marked difference in traditional and virtual banks' prudential performance is indicative of segmentation in the respective entities' client bases. Results are consistent with 
traditional banks' retention of more conservative, risk-averse clients; and Fintech entities' appeal to a more diverse, "techno-savvy" group of younger investors. Significant wealth differences are also likely between the client groups. Quantification of such segmentation effects awaits further inquiry [See earlier discussions and Endnote 3]. However, such investigation lies outside the scope of the present study.

\subsection{Comparison of traditional bank and Fintech entities' descriptive statistics}

Building on background trends captured in Fig. 1, Table 2 reports descriptive statistics on the four performance measures (ROA, ROE, NPL and SML). Panel A presents descriptive statistics for traditional bank lenders. The remaining parts of Table 2 report performance statistics for lenders from state-owned (Panel B), joint stock commercial (Panel C), city commercial (Panel D), rural commercial (Panel E) and Fintech (Panel F) sectors.

For 2013-2019, profitability is greater among traditional banks than Fintech firms. Fintech entities register mean negative returns on both asset and equity (ROA and ROE). In contrast, traditional bank levels are $0.96 \%$ and $1.47 \%$ (see Table 2, Panel B). Additionally, Fintech companies' non-performing loan (NPL) rates are more than three times those of traditional banks. Special mention loans (SML) follow a similar pattern, with rates twice as high for Fintech entities.

Within the group of traditional banks, state-owned banks (SBs) rank first in terms of ROA and second, behind joint-stock commercial banks (JSCBs), in terms of ROE. However, NPL rates are higher for these two groups compared to city commercial (CCBs) and rural commercial banks (RCBs). The higher NPL ratios suggest that SBs and JSCBs engage in riskier activities. One explanation is the "too big to fail effect" (Fan et al. 2012; Liang et al. 2014), inducing large banks to accept greater risk. However, Wang et al. (2018) demonstrate that the return "volatility connectedness" is lower among SBs than JSCBs.

SBs' proximity to the state may nonetheless induce pressure to support strategically important but non-profit making industries. Adverse selection risk may also be higher if SOE borrowers' executive compensation schemes incentivize non-disclosure of risk factors (Xu et al. 2014).

Table 3 presents summary statistics of explanatory variables. Panels A-E and F report respective statistics for traditional banks and Fintech lenders. Credit risk, as captured by LLP, is much higher for Fintech companies than for traditional banks (7.62\% vs $3.06 \%$ ). Indeed, regulations require Fintech companies to set aside more funds to cover credit risks (Caixin 2020). This requirement reflects Fintech entities'strong growth orientation, as compared to traditional banks' value focus. The gap in price-to-book (MB) valuations (19.76 versus 0.82) characterizes this difference. Moreover, many Chinese banks experienced MB ratios below 1.0 during the period (Cai 2014). Within the traditional bank group, larger banks, notably JSCBs and SBs display the lowest LLP ratios. Such banks' greater access to state capital also mitigates the need for significant loan loss provisions. RCBs are the least risky traditional banks in terms of LLP ratios.

Liquidity ratios (=liquid assets/total assets) are notably higher for Fintech lenders compared to traditional banks (31.36\% vs $14.20 \%)$. Such difference likely reflects Fintech entities' preference for cash holdings to cover near-term technology and R\&D expenditures. In contrast, traditional banks place greater reliance on longer-term investment. Within the traditional bank groups, JSCBs have the lowest liquidity ratio (12.54\%) and SBs the highest (16.90\%). 
Table 2 Descriptive statistics of performance (ROA, ROE, NPL and SML) by ownership type

\begin{tabular}{llllll}
\hline & \multicolumn{4}{l}{ Panel A: All traditional banks } & \\
\cline { 2 - 5 } & Obs & Mean & Min & Max & Std Dev \\
\hline ROA & 213 & 0.0096 & 0.0015 & 0.0146 & 0.0022 \\
ROE & 213 & 0.1469 & 0.0205 & 0.2622 & 0.0360 \\
NPL & 213 & 0.0140 & 0.0039 & 0.0247 & 0.0042 \\
SML & 213 & 0.0269 & 0.0055 & 0.0961 & 0.0130 \\
\hline
\end{tabular}

Panel B: State-Owned Banks

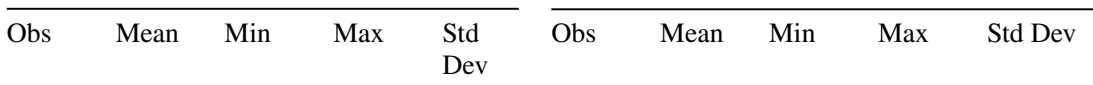

\begin{tabular}{lllllllllll}
\hline ROA & 39 & 0.0104 & 0.0051 & 0.0146 & 0.0024 & 60 & 0.0098 & 0.0071 & 0.0139 & 0.0019 \\
ROE & 39 & 0.15 & 0.1117 & 0.2190 & 0.0296 & 60 & 0.1561 & 0.1023 & 0.2344 & 0.0316 \\
NPL & 39 & 0.0151 & 0.0075 & 0.0239 & 0.0045 & 60 & 0.0146 & 0.0074 & 0.0214 & 0.0034 \\
SML & 39 & 0.0273 & 0.0063 & 0.0447 & 0.0094 & 60 & 0.0261 & 0.0064 & 0.0460 & 0.0103 \\
\hline
\end{tabular}

Panel D: City Commercial banks Panel E: Rural Commercial banks

\begin{tabular}{|c|c|c|c|c|c|c|c|c|c|}
\hline Obs & Mean & Min & $\operatorname{Max}$ & $\begin{array}{l}\text { Std } \\
\text { Dev }\end{array}$ & Obs & Mean & Min & $\operatorname{Max}$ & Std Dev \\
\hline
\end{tabular}

\begin{tabular}{lllllllllll}
\hline ROA & 101 & 0.0092 & 0.0015 & 0.0143 & 0.0023 & 13 & 0.0101 & 0.0084 & 0.0128 & 0.0013 \\
ROE & 101 & 0.1407 & 0.0205 & 0.2622 & 0.0411 & 13 & 0.1436 & 0.1231 & 0.1727 & 0.0182 \\
NPL & 101 & 0.0133 & 0.0039 & 0.0247 & 0.0046 & 13 & 0.0126 & 0.0078 & 0.0186 & 0.0035 \\
SML & 101 & 0.0259 & 0.0055 & 0.0580 & 0.0134 & 13 & 0.0360 & 0.0179 & 0.0961 & 0.0242 \\
\hline
\end{tabular}

Panel F: Fin-

techs

\begin{tabular}{llllll} 
& Obs & Mean & Min & Max & Std Dev \\
\hline ROA & 93 & -0.0864 & -11.0714 & 0.7632 & 1.1852 \\
ROE $_{2}$ & 87 & -1.0872 & -73.8889 & 0.8031 & 8.3543 \\
NPL & 93 & 0.0485 & 0.0017 & 0.5820 & 0.0771 \\
SML & 93 & 0.0572 & 0.0034 & 0.3345 & 0.0473 \\
\hline
\end{tabular}

2. Exclude extreme values over $|20|$, summary statistics become: $\mathrm{N}=84$; average 0.0370 ; $\min .=-3.4340$; $\max .=0.0831 ;$ and standard deviation $=0.6115$

ROA (Return-on-assets); ROE (Return-on-equity); NPL (Percentage of loans reported as "Non-Performing"); and SML (Percentage of loans reported as "Special Mention")

Relative to Fintech entities, traditional banks have a much lower equity to total assets ratio, EA (46.44\% vs $6.99 \%)$. This difference reflects Fintech organizations' strong reliance on external capital funding. Within the traditional bank group, uniform EA levels (of around 7\%) are apparent. Similarly, Fintech entities' operational risk $\left(\mathrm{C}_{\mathrm{t}} / \mathrm{C}_{\mathrm{t}-1}\right)$ dwarfs that of traditional banks ( 2.33 vs 1.15$)$. High recurrent costs in running digitalization and ecommerce platforms likely underlie this difference. Software/hardware costs, R\&D expenditures and ecommerce access and distribution fees likely drive this difference. Among traditional banks, SBs (RCBs) display the lowest (highest) year-on-year increase in operating costs 1.07 (1.25). In sum, $\mathrm{C}_{\mathrm{t}} / \mathrm{C}_{\mathrm{t}-1}$ flags the importance of operating efficiency in relation to a lender's profitability (Fang et al. 2019). Nonetheless, Wang et al 
Table 3 Descriptive statistics for explanatory variables (2013-2019)

\begin{tabular}{|c|c|c|c|c|c|c|c|c|c|c|}
\hline & & Panel A: Al & 1 traditior & nal banks & & & & & & \\
\hline & & Obs & & Mean & Min & & Max & & Std Dev & \\
\hline LLP & & 213 & & 0.0306 & 0.01 & & 0.0506 & & 0.0067 & \\
\hline LQ & & 213 & & 0.1420 & 0.06 & & 0.3458 & & 0.0495 & \\
\hline EA & & 213 & & 0.0699 & 0.04 & & 0.1355 & & 0.0107 & \\
\hline $\mathrm{Ct} / \mathrm{Ct}_{-1}$ & & 213 & & 1.1545 & 0.79 & & 2.4884 & & 0.1696 & \\
\hline VaR & & 213 & & 77.9568 & 0.40 & & 784 & & 111.457 & \\
\hline MB & & 202 & & 0.8199 & 0.12 & & 1.5879 & & 0.2655 & \\
\hline S & & 213 & & 14.4382 & 11.1 & 687 & 17.220 & & 1.4244 & \\
\hline TimeList & & 202 & & 4.0415 & 0 & & 5.8435 & & 1.2154 & \\
\hline $\mathrm{DPOR}_{\mathrm{t}-1}$ & & 213 & & 0.2367 & 0 & & 0.5405 & & 0.1035 & \\
\hline & Panel & State-Owne & d Banks & & & Pane & oint Stock & Commerci & 1 Banks & \\
\hline & Obs & Mean & Min & Max & Std Dev & Obs & Mean & Min & $\operatorname{Max}$ & Std Dev \\
\hline LLP & 39 & 0.0289 & 0.0222 & 0.0453 & 0.0069 & 60 & 0.0281 & 0.0179 & 0.0497 & 0.0058 \\
\hline LQ & 39 & 0.1690 & 0.1158 & 0.2454 & 0.0334 & 60 & 0.1254 & 0.0658 & 0.1936 & 0.0360 \\
\hline EA & 39 & 0.0736 & 0.0420 & 0.0894 & 0.0111 & 60 & 0.0671 & 0.0505 & 0.0892 & 0.0083 \\
\hline $\mathrm{Ct} / \mathrm{Ct}_{-1}$ & 39 & 1.0714 & 0.9017 & 1.1846 & 0.0641 & 60 & 1.1326 & 0.8166 & 1.7245 & 0.1291 \\
\hline VaR & 39 & 198.8326 & 15.89 & 784 & 183.9339 & 60 & 108.8783 & 11.5 & 370.8 & 73.5298 \\
\hline MB & 39 & 0.8418 & 0.5270 & 1.3577 & 0.1775 & 60 & 0.8587 & 0.4334 & 1.5573 & 0.2630 \\
\hline S & 39 & 16.5715 & 15.601 & 17.22 & 0.4462 & 60 & 15.1898 & 14.1192 & 15.8193 & 0.4623 \\
\hline TimeList & 39 & 4.5461 & 1.3863 & 5.1648 & 0.7304 & 60 & 4.9171 & 2.3026 & 5.8435 & 0.6579 \\
\hline $\mathrm{DPOR}_{\mathrm{t}-1}$ & 39 & 0.3053 & 0.1340 & 0.35 & 0.0329 & 60 & 0.2122 & 0 & 0.3750 & 0.0943 \\
\hline
\end{tabular}

\begin{tabular}{|c|c|c|c|c|c|c|c|c|c|c|}
\hline & \multicolumn{5}{|c|}{ Panel D: City Commercial banks } & \multicolumn{5}{|c|}{ Panel E: Rural Commercial banks } \\
\hline & Obs & Mean & Min & $\operatorname{Max}$ & Std Dev & Obs & Mean & Min & $\operatorname{Max}$ & Std Dev \\
\hline LLP & 101 & 0.0313 & 0.0170 & 0.0436 & 0.0057 & 13 & 0.0406 & 0.0283 & 0.0506 & 0.0063 \\
\hline LQ & 101 & 0.1413 & 0.0692 & 0.3458 & 0.0587 & 13 & 0.1427 & 0.0899 & 0.1840 & 0.0289 \\
\hline EA & 101 & 0.0698 & 0.0507 & 0.1355 & 0.0118 & 13 & 0.0731 & 0.0659 & 0.0868 & 0.0059 \\
\hline $\mathrm{Ct} / \mathrm{Ct}_{-1}$ & 101 & 1.1878 & 0.7930 & 2.2953 & 0.1635 & 13 & 1.2452 & 0.9184 & 2.4884 & 0.3877 \\
\hline $\mathrm{VaR}$ & 101 & 21.9656 & 1.5 & 77.5 & 14.2244 & 13 & 7.6231 & 0.4000 & 18.2 & 7.3023 \\
\hline MB & 92 & 0.7860 & 0.1239 & 1.5879 & 0.2952 & 11 & 0.8137 & 0.4430 & 1.3813 & 0.3902 \\
\hline $\mathrm{S}$ & 101 & 13.3096 & 11.1687 & 14.8224 & 0.7181 & 13 & 13.3379 & 12.4334 & 13.8449 & 0.4700 \\
\hline TimeList & 92 & 3.0381 & 0 & 5.0106 & 1.4739 & 11 & 3.6582 & 1.9459 & 4.6913 & 0.9227 \\
\hline \multirow[t]{3}{*}{$\underline{\text { DPOR }_{\mathrm{t}-1}}$} & 101 & 0.2241 & 0 & 0.5405 & 0.1179 & 13 & 0.2413 & 0 & 0.3175 & 0.0808 \\
\hline & \multicolumn{10}{|c|}{ Panel F: Fintechs } \\
\hline & \multicolumn{2}{|l|}{ Obs } & \multicolumn{2}{|c|}{ Mean } & \multicolumn{2}{|l|}{ Min } & \multicolumn{2}{|r|}{ Max } & \multicolumn{2}{|r|}{ Std Dev } \\
\hline LLP & \multicolumn{2}{|l|}{93} & \multicolumn{2}{|c|}{0.0762} & \multicolumn{2}{|l|}{0.0042} & \multicolumn{2}{|r|}{0.9260} & \multicolumn{2}{|r|}{0.1123} \\
\hline LQ & \multicolumn{2}{|l|}{93} & \multicolumn{2}{|c|}{0.3136} & \multicolumn{2}{|l|}{0.0000} & \multicolumn{2}{|r|}{0.8367} & \multicolumn{2}{|r|}{0.2437} \\
\hline EA & \multicolumn{2}{|l|}{93} & \multicolumn{2}{|c|}{0.4644} & \multicolumn{2}{|l|}{-2.0602} & \multicolumn{2}{|r|}{0.9701} & \multicolumn{2}{|r|}{0.4250} \\
\hline $\mathrm{Ct} / \mathrm{Ct}_{-1}$ & \multicolumn{2}{|l|}{93} & \multicolumn{2}{|c|}{2.3283} & \multicolumn{2}{|l|}{0.0636} & \multicolumn{2}{|r|}{26.5799} & \multicolumn{2}{|r|}{3.6610} \\
\hline $\mathrm{VaR}$ & \multicolumn{2}{|l|}{93} & \multicolumn{2}{|c|}{5.7015} & \multicolumn{2}{|l|}{0.0200} & \multicolumn{2}{|r|}{38.3000} & & 6.9759 \\
\hline MB & 81 & & 19.7 & & -10.586 & & & 884.4937 & & 98.6915 \\
\hline $\mathrm{S}$ & 93 & & 7.94 & & 3.6672 & & & 9.9211 & & 1.4365 \\
\hline TimeList & 81 & & 2.72 & & 0 & & & 4.7005 & & 1.2889 \\
\hline $\mathrm{DPOR}_{\mathrm{t}-1}$ & 81 & & 0.08 & & 0 & & & 1.1667 & & 0.2370 \\
\hline
\end{tabular}


Table 4 Descriptive statistics for industry and macroeconomic variables

\begin{tabular}{llllll}
\hline & Obs & Mean & Mini & Max & Std Dev \\
\hline Fintech & 213 & 9.6012 & 8.7919 & 9.8384 & 0.3956 \\
CapMkt & 213 & 0.5906 & 0.4126 & 0.7402 & 0.1226 \\
INF & 213 & 0.0209 & 0.0140 & 0.0290 & 0.0052 \\
LIR-SIR & 213 & 0.0131 & 0.0036 & 0.0241 & 0.0065 \\
RRR & 213 & 0.1642 & 0.1070 & 0.1950 & 0.0322 \\
\hline
\end{tabular}

LLP (Loan loss provisions/total loans); LQ (Liquid assets/total assets); EA (Total equity/total assets); Ct/Ct- ${ }_{1}$ (Current period's costs/ previous period's costs); VaR (Value-at-Risk); DPOR (Dividends $_{\mathrm{t}-1}$ / net profit $t_{\mathrm{t}-1}$ )*100; ForStr (Dummy for one or more foreign strategic owners); SB (Dummy for State-owned Banks); JSCB (Dummy for Joint-Stock Commercial Banks); CCB (Dummy for City Commercial Banks); TimeList (Time since IPO); MB (Market to book of net assets; S (Log of total assets); Fintech (Log of number of Fintech firms); CapMkt (Market cap of listed companies/GDP); RRR (Reserve Ratio Requirement \%); INF (Inflation rate); and LIR-SIR (Long-short term interest rate)

(2021) report efficiency gains (in relation to factor productivity) from Chinese banks' adoption of Fintech, and most notably in the area of Big Data.

Fintech entities also embrace greater market risk. Major differences in one-day value loss exposure exist between traditional bank and Fintech entities (77.96 vs 5.70). Among traditional banks, SBs (RCBs) exhibit by far the highest (lowest) VaR levels.

Table 3 reveals notable difference in TimeList values between traditional bank and Fintech entities. Traditional banks' dividend pay-out ratios are materially higher $(23.67 \%$ vs $8.00 \%)$. Such difference reflects Fintech entities' reinvestment of profit into growth options. Within the traditional bank sector, SBs distribute the most generous dividends on average (30.53\%). This outcome reflects SOEs' greater inclination to distribute profit (McGuinness et al 2015). Welker et al. (2017) report regulatory incentives to distribute dividends for Chinese issuers planning equity issues. Forti and Schiozer (2015) identify the importance of dividend signaling post-GFC.

Table 4 reports descriptive statistics on macroeconomic and industry variables. The greatest variation is evident in market cap to GDP. A number of factors account for stock return volatility in China. These include limits on arbitrage ( $\mathrm{Gu}$ et al. 2018), oil prices (Wen et al. 2019; Wang et al. 2019; and Xu et al. 2019), share reforms (Tan 2016) and short-selling restrictions (Xiong et al. 2017). Variation in inflation, interest rate spreads and reserve ratio requirements appear small in comparison. Such a picture reflects a period of relative stability in monetary policy (Chen et al. 2017). Table 4 also reveals major change in the number of Fintech entities, highlighting the evolving membership of China's digital community (Leong et al. 2017).

Tables 15 and 16 report bivariate correlations for bank and Fintech groupings.

\subsection{Estimation results}

\subsubsection{Fixed effects estimation results for Chinese banks}

Table 5 presents empirical results from fixed effects regressions (without interaction terms) for the 40 Chinese listed banks. Hausman tests reveal a significant difference (at the 1\% 
Table 5 Fixed-effects estimation results (without interaction terms) for the traditional banks

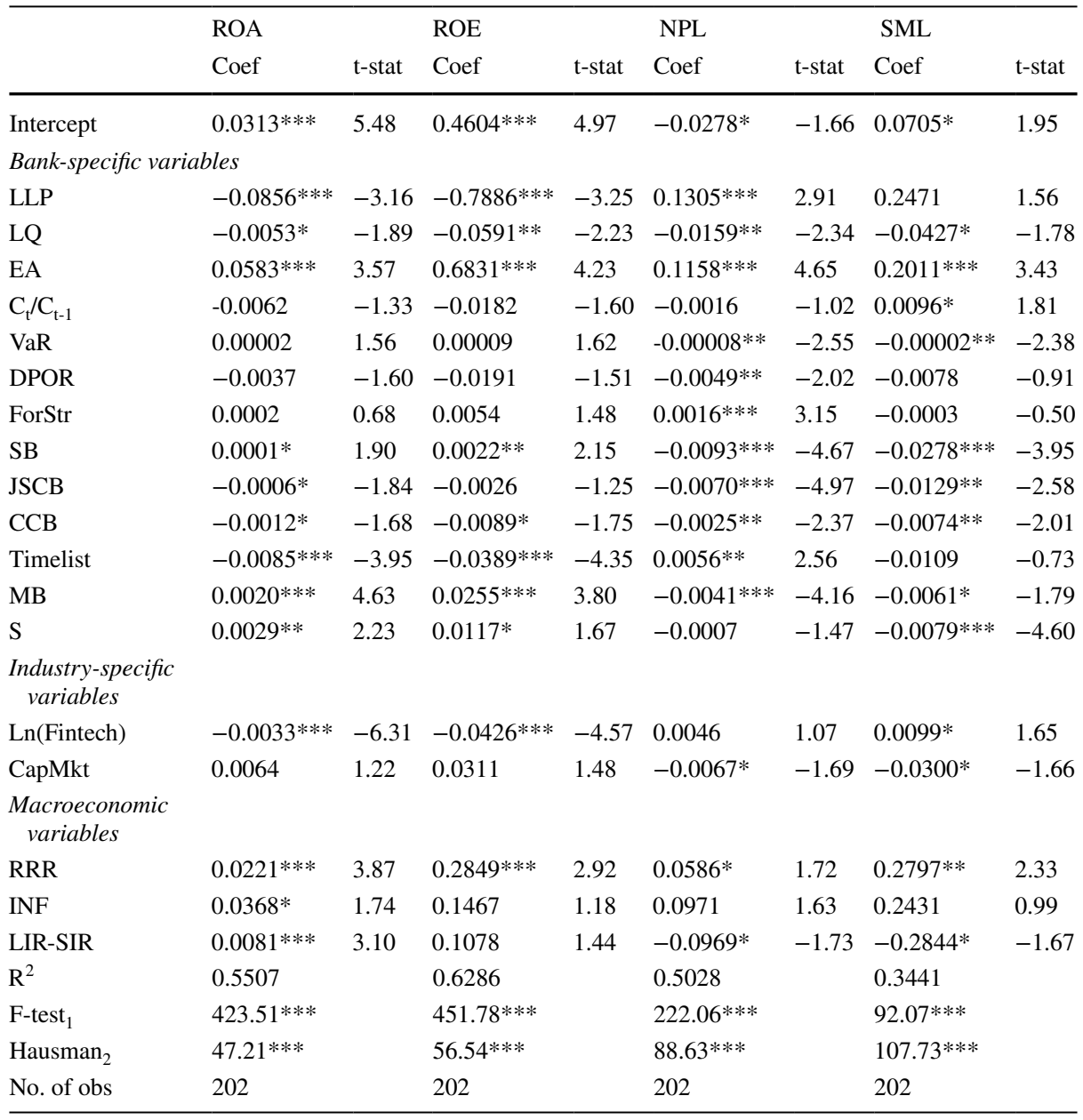

$* * *, * *$ and $*$ denote statistical significance at the $1 \%, 5 \%$ and $10 \%$ level, respectively

1. The F-statistic of the overall significance of the equation $\left(\mathrm{H}_{0}\right.$ : all explanatory variables' coefficients are equal to zero)

2. The Hausman test invites support for a fixed, rather than random, effects specification

LLP (Loan loss provisions/total loans); LQ (Liquid assets/total assets); EA (Total equity/total assets); Ct/ $\mathrm{Ct}_{-1}$ (Current period's running costs/previous period's running costs); VaR (Value-at-Risk); DPOR ${ }_{\mathrm{t}-1}$ (Dividends $_{\mathrm{t}-1} /$ net profit $_{\mathrm{t}-1}$ )*100; ForStr (Dummy for one or more foreign strategic owners); SB (Dummy for State-owned Banks); JSCB (Dummy for Joint-Stock Commercial Banks); CCB (Dummy for City Commercial Banks); TimeList (Time since IPO); MB (Market to book of net assets; S (Log of total assets); Fintech (Log of number of Fintech firms); CapMkt (Market cap of listed companies/GDP); RRR (Reserve Ratio Requirement \%); INF (Inflation rate); and LIR-SIR (Long-short term interest rate)

level) in coefficients between fixed and random effects models in all four regression specifications. Accordingly, we deem a fixed effects approach appropriate. Additionally, F-test statistics suggest the rejection of the null hypothesis of no joint significance (at the $1 \%$ level) in all four equations. 
Results in Table 5 highlight a significant inverse association between LLP and bank profitability (ROA and ROE). Findings also suggest that rising credit risk quickly impinges on NPL positions. All of these outcomes offer support for Hypothesis 1. Consistent with the notion of liquidity as an expense, the coefficient on LQ is also negative and significant in ROA and ROE equations. Such findings support the contention in Hypothesis 2 that increased loan exposure (and illiquidity) induces higher bank profitability. According to Tan (2016), such an outcome is congruent with Chinese banks' effective loan management. Results for NPL and SML equations in Table 5 suggest a significant positive relation between liquidity and prudential bank performance.

Results in the ROA and ROE equations of Table 5 indicate a significant positive link between bank profitability and the ratio of total equity to total assets (EA). As capital risk bears inverse relation to EA, findings support the contention in Hypothesis 3. In effect, banks' robust capital position protects against unexpected losses (Athanasoglou et al. 2008). However, the significant positive coefficient on EA in NPL and SML regressions suggests banks raise capital to protect against an anticipated decline in prudential performance.

Table 5 results indicate that operational risk $\left(\mathrm{C}_{\mathrm{t}} / \mathrm{C}_{\mathrm{t}-1}\right)$ has significant impact on SML and not NPL positions. Accordingly, there is only modest backing for Hypothesis 4 in relation to prudential bank performance. The coefficient on value-at-risk (VaR) is significant and negative in NPL and SML regressions. Such results offer support for the contention in Hypothesis 5 of a positive association between market risk and prudential performance. The estimated VaR coefficient is, nonetheless, small in all Table 5 regressions.

With regard to our sixth hypothesis, Table 5 reveals an inverse but insignificant association between dividend payout ratios (DPOR) and bank profitability. However, lower dividend payout, and thus greater reinvestment of profit, correlates with growing NPL concerns.

We also find support for the premise in Hypothesis 7 that performance deteriorates postIPO (TimeList). The association is negative in ROA and ROE equations and positive in NPL equation. Results are consistent with banks listing when profit and asset quality are at near-term highs.

The dummy for foreign strategic equity holdings (ForStr) has a positive and significant relation with NPLs in Table 5. This outcome runs counter to Hypothesis 9. It reveals lower asset quality in bank entities with strategic foreign equity ownership. Luo et al. (2017) report that foreign banks' establishment of branch networks in China instills efficiency gains in domestic banks. Results herein suggest counter effects when foreign parties establish equity stakes in domestic banks.

The impact of state ownership on profitability is also important. In terms of both ROA and ROE, state-owned commercial (SB) banks exhibit stronger profitability than JSCB, CCB and RCB entities. Results contrast with earlier evidence in Herrero et al. (2009) of enhanced JSCB performance. Findings on bank ownership in the Fintech era also contrast with results in Tan (2016), where city commercial banks yield a performance advantage. Ownership effects are thus very much time or study period dependent. The Fintech era of 2013-2019 offers important contrast with earlier studies. Our results for the Fintech era suggest greater profit resilience in large state-owned banks. Moreover, we surmise that SBs' funding and political connections conferred major advantage during the recent period of Fintech disruption. The listing of SBs since 2005 has also helped in galvanizing banks' governance and commercial lending policies (Jia 2009).

When examining NPL and SML performance indicators, we observe a negative relation with each of the three ownership dummies (SB, JSCB and CCB). Relative to rural banks, 
higher asset quality is evident in the three bank sectors. Consistent with He et al. (2017), state banks (SBs) demonstrate greater NP stability. Instructively, the SB dummy coefficient is larger than that for either JSCB or CCB dummies in Table 5 NPL regressions. Accordingly, results offer support for the contention in Hypothesis 8 of stronger financial and prudential performance in state-held banks.

For control variables, $\mathrm{MB}$ is strongly significant in all four equations in Table 5. The coefficient on MB is positive (negative) in ROA and ROE (NPL and SML) equations. Results suggest that growth options promote profitability and asset quality. Similarly, bank size (S) is significant in three out of four equations. Larger banks secure higher asset quality (through lower SML rates) and enhanced profitability. The positive impact of bank size on profitability supports an economies of scale narrative, and the attendant "too-big-tofail" argument (Goddard et al. 2004b; Iannotta et al. 2007). Bank size also functions as a surrogate for political connections (Garcia-Herrero et al. 2009).

Variable Fintech exerts significant negative effect on bank profitability. Such an outcome underscores this study's central premise: Fintech competition erodes traditional bank profitability. Evidence herein is consistent with Phan et al. (2019). Results in Column 4 of Table 5 indicate that increased Fintech competition correlates with rising (and thus weaker) SML positions. Results also point to a significant positive relation between capital market maturity (CapMkt) and prudential performance. This outcome extends the narrative, in Tan (2016, p. 92), by which equity market development supports bank financial performance. Borrower stock price reactions to loan announcements also inform on possible expropriation within the debtor entity (Huang et al. 2012). Such signals are increasingly important in light of China's growing number of listed companies.

We also control for China's reserve ratio requirement (RRR). Interestingly, RRR is increasing (decreasing) in bank profitability (asset quality) in Table 5. Additionally, and as in García-Herrero et al. (2009) and Tan (2016), a positive link exists between inflation (INF) and bank profitability. A narrowing of lending and funding margins (LIR-SIR) also weakens banks' ROA and loan quality.

Table 6 reports fixed effects estimation results with interaction effects. Again, Hausman test results offer support for a fixed effects model approach in all four specifications. Significant interaction effects exist between risk variables and Ln (Fintech). The negative coefficient on Var* Ln (Fintech) suggests magnification of the positive effect of market risk on prudential performance (i.e., lower NPL and SML rates) as Fintech competition intensifies. In contrast, the positive effect of market risk on profitability (ROA and ROE) weakens with an increasing number of Fintech firms. Additionally, the adverse effect of credit risk (LLP) on profitability weakens with Fintech competition. The negative effect of liquidity (LQ) on ROE also weakens with Fintech competition, whereas the positive impact of liquidity on prudential performance intensifies with it. The opposite result is found for the capital variable (EA), where the positive association between capital and ROE weakens when Fintech competition intensifies. The positive and significant effect of EA*Fintech on SML rates suggests intensification of the negative association between excess capital and prudential performance during periods of rising Fintech numbers. 


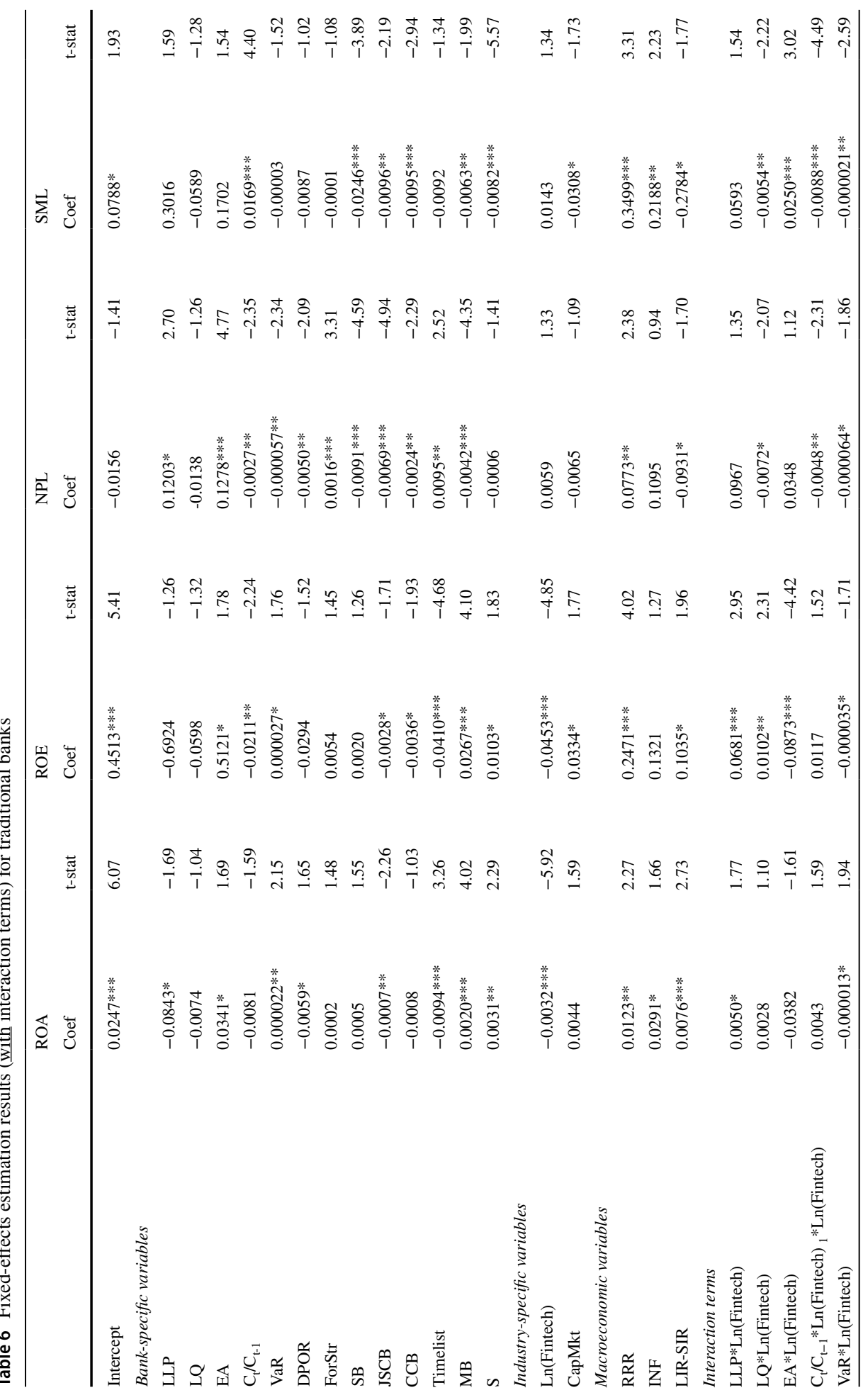




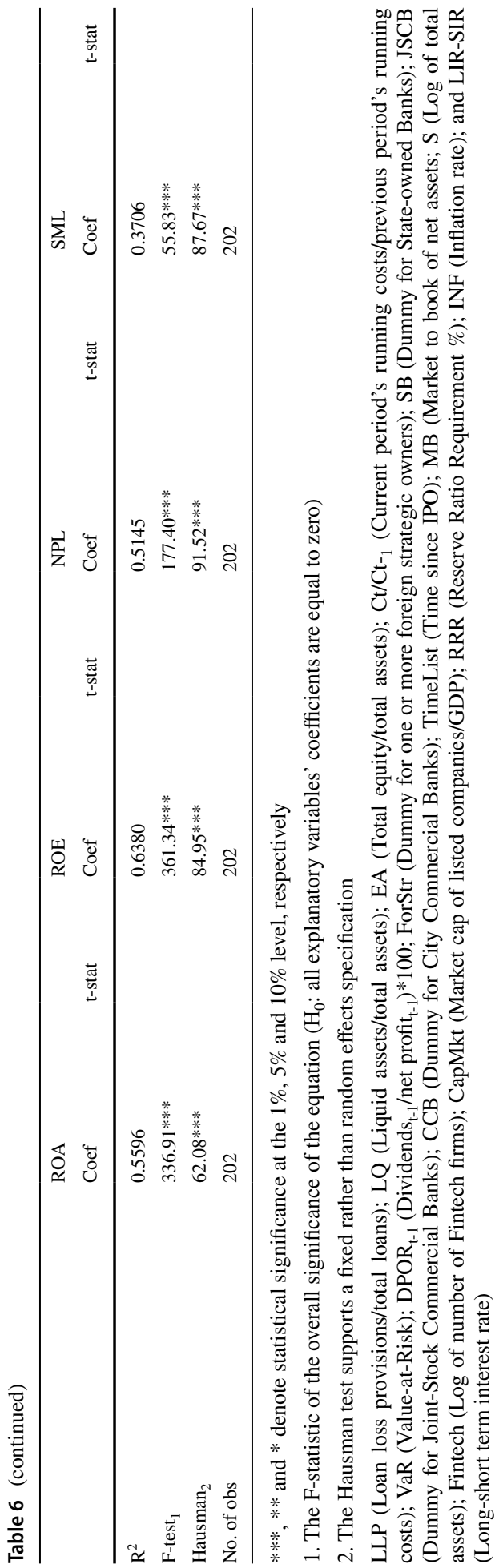




\subsubsection{GMM estimation results for Chinese banks}

Table 7 reports GMM estimation results within a dynamic model setting featuring lagged performance (but excluding interaction effects). ${ }^{27}$ The magnitude of the coefficient on prior period performance is not only insignificant in two of the four regressions but also close to zero. Consistent with a competitive banking sector, performance effects are not persistent. Our results on this issue are broadly consistent with earlier findings in Tan (2016).

Overall, GMM and fixed effects results appear similar. Consistent with Hypothesis 1, higher credit risk inhibits profitability and asset quality. Table 7 regressions also signal some support for Hypothesis 2. Specifically, greater bank liquidity weakens profitability but supports prudential (loan quality) performance. Similar to Table 5, support for Hypothesis 3 is positive in relation to bank profitability but negative in terms of prudential effects. In particular, Table 7 results reveal that capital (EA) supports ROA and ROE performance but weakens loan quality (given rising to higher NPL and SML rates). Similar to fixed effect estimations, increased operational risk impairs asset quality (in relation to SML rates). As with Tables 5, 7 reveals that greater market risk improves NPL and SML rates. It also improves ROE bank performance. Such outcomes support Hypothesis 5. Again, the magnitude of estimated VaR coefficients are small.

Findings in Table 7 also support Hypothesis 6. Results suggest that lower dividend payout supports profitability. However, banks' greater reinvestment of profit appears to weaken SML positions. GMM regressions also confirm the positive association between foreign strategic investor presence and performance (in terms of ROA and SML) In contrast, strategic foreign equity ownership correlates with weaker prudential performance (through higher NPL rates). Similar to fixed effects estimations, state-owned lenders (SBs) register stronger bank profitability. Based on the size of estimated coefficients, SBs are also more resilient in prudential terms (especially in relation to SMLs). As with Table 5, results in Table 7 reveal that financial and NPL performance weaken with time since IPO. Findings thus offer broad support for Hypothesis 8 . Table 7 results suggest bank profitability and asset quality are increasing in $\mathrm{MB}$ and total assets (S).

Industry-specific and macroeconomic effects noted earlier remain intact. In particular, the rising number of Fintech firms has negative impact on banks' ROE performance. Table 7 also confirms a positive and significant relationship between capital market maturity and prudential performance (as shown by the negative coefficient on CapMkt in NPL and SML regressions). As corroboration of Tan (2016, p. 92), capital market maturity also supports bank profitability. Table 7 results also show that narrower interest rate spreads (LIR-SIR) weaken ROE profitability. ${ }^{28}$

27 .F-test statistics again reveal the joint significance of variables. The Sargan (1985) test also confirms EA as the appropriate endogenous variable. Arellano-Bond (1991) test results for serial correlation further suggest that the null of no second order serial correlation cannot be rejected. GMM estimation is appropriate given inconsistency issues as implied from second-order autocorrelation (Arellano and Bond 1991).

28 .As an additional robustness test, we also conduct GMM analysis with fewer variates. After removal of explanatory variables RRR, INF, LIR-SIR \& CapMkt, the sign of associations and the ordering of significance of variables remains largely unchanged. This additional stage of analysis suggests that findings are generally robust to model type (Fixed effect versus GMM), as well as to number of variates considered. We thank an anonymous reviewer for input on this issue. For reasons of parsimony, we do not report the additional GMM results (based on fewer variates). 
| 


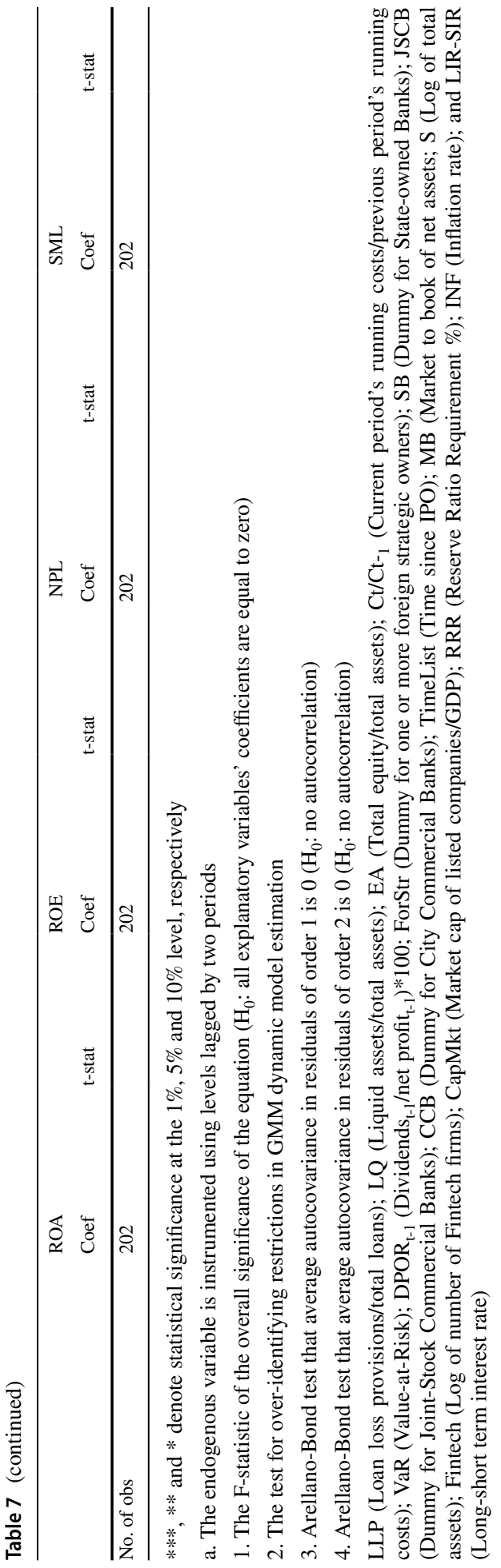


Table 8 regressions incorporates risk factor interactions with number of Fintech firms. ${ }^{29}$ First, the negative impact of credit risk on ROE performance becomes less pronounced with increased Fintech competition. Stronger Fintech competition also exacerbates traditional banks' SML rates. Second, as Fintech numbers rise, the adverse effect of bank liquidity on profitability weakens and the negative effect on NPL rates intensifies. Accordingly, greater Fintech competition strengthens the positive impact of liquidity on asset quality (in view of lower NPL rates). Third, Fintech competition weakens the positive link between capital and profitability. In contrast, Fintech competition supports the role of equity capital in arresting SML rates. Fourth, Fintech interaction with operational risk results in lower NPLs. In GMM regressions, rising Fintech competition accentuates the positive impact of operational risk on ROA. Finally, as Fintech numbers rise, the positive relation between market risk and loan quality strengthens.

\subsubsection{Fixed effect and GMM estimation results for Chinese Fintech entities}

In a further stage of analysis, we investigate the determinants of financial and prudential performance for the group of 25 exchange-listed Chinese Fintech companies featured in this study. Tables 9 and 10 report relevant regression results. A number of broad and consistent themes emerge in relation to both fixed effect (Table 9) and GMM (Table 10) estimation approaches.

In relation to prudential performance, the important risk factors are LLP and VaR. Moreover, the direction of association is consistent with the underlying postulates in Hypotheses 1 and 5. For financial performance, the strongest associations with risk factors are evident in GMM results (Table 10). In particular, higher equity capital (EA) and market risk (VaR) levels strongly underpin financial performance. These outcomes provide important support for Hypotheses 3 and 5.

In contrast to the traditional bank group, performance in the Fintech sphere bears little to no association with dividends. Consistent with Hypothesis 6, this result reflects online lenders' overarching need for cash for investment in growth options. Due, perhaps, to the very short period of exchange listing of all 25 Fintech entities, variable Timelist displays weak association with all performance measures. As a consequence, there is little to no support for Hypothesis 7 in respect to online lenders. This outcome contrasts with the strong support evident for banks.

As with traditional banks, asset size matters. Results in Tables 9, 10 reveal greater resilience in larger Fintech outfits (given a significant positive relation between $S$ and each of ROA and ROE). However, asset quality bears inverse relation with online lender size (i.e., NPL and SML rates are increasing in S). Results also reveal that greater capital market development (CapMkt) is beneficial to Fintech firms in respect to financial and prudential outcomes. Results in this area appear stronger for Fintech than traditional banks. This finding most likely reflects Fintech entities' greater dependence on external funding channels, most especially in respect to equity markets. Results in this area offer important development of Tan's (2016) findings on the role

29 .Based on a Sargan (1985) test, there is no evidence of over-identification restrictions. Arellano-Bond (1991) test results also offer insufficient evidence to reject the null of no second order serial autocorrelation. We also confirm the dynamic nature of the model for ROE, SML and NPL equations. The small coefficients on lagged performance suggest the absence of persistence effects. 
| 


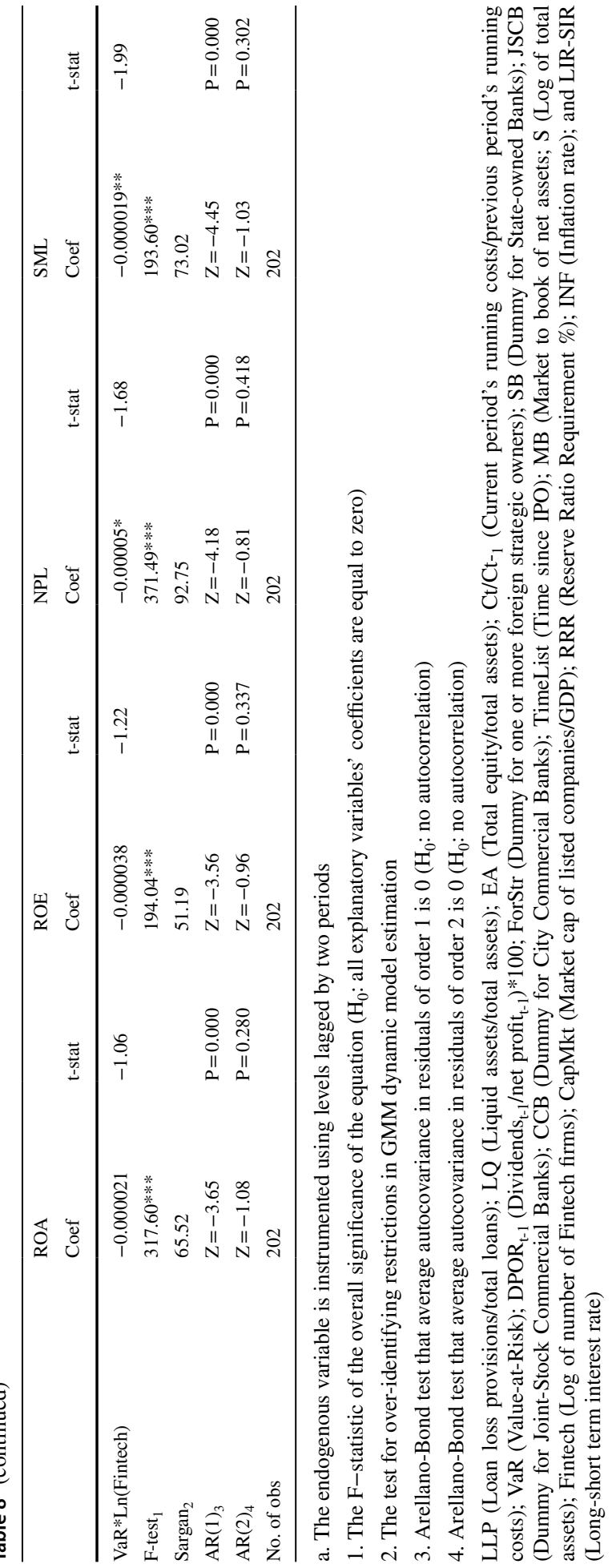


Table 9 Fixed-effects estimation results for the subsample of Fintech entities

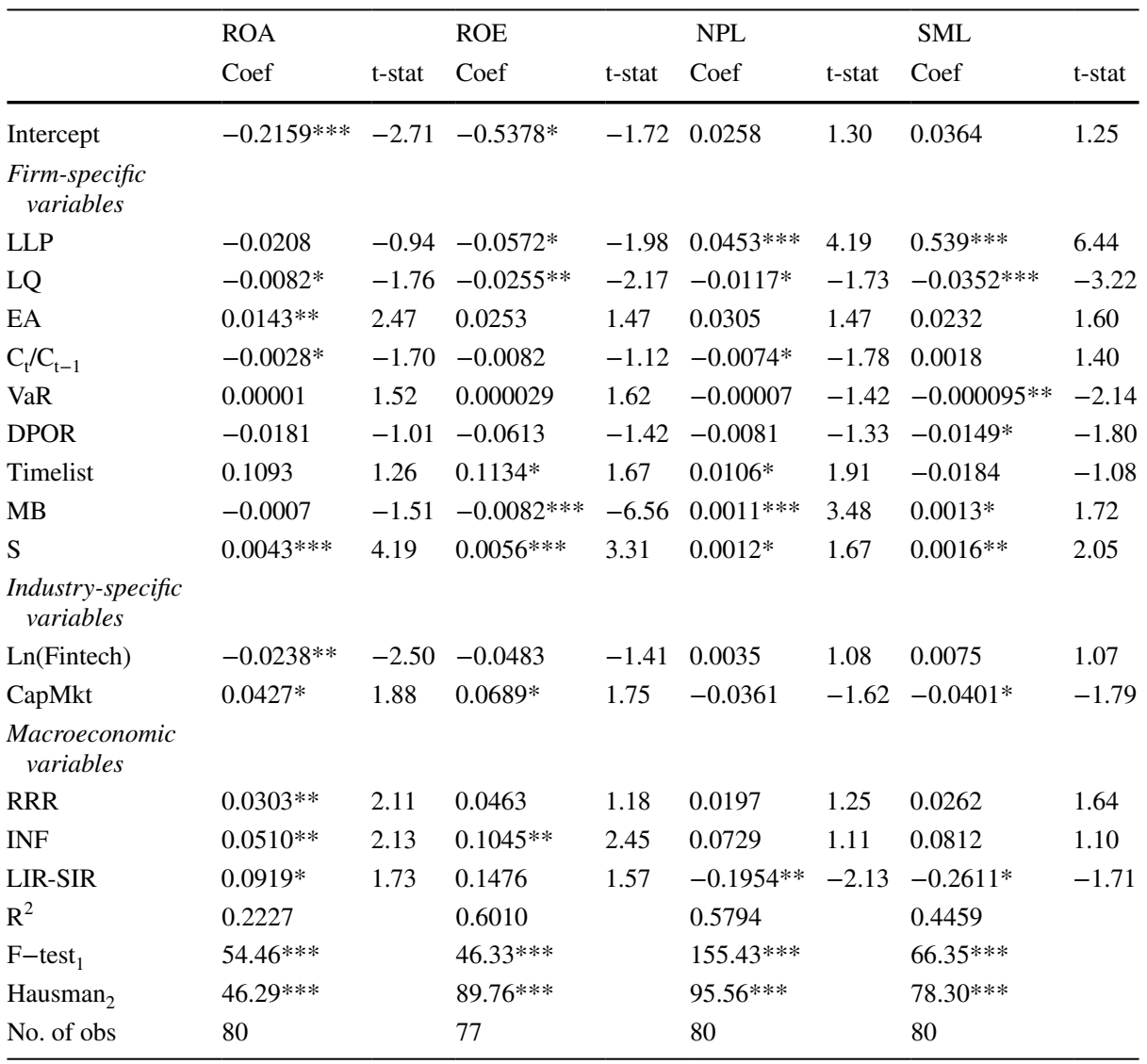

$* * *, * *$ and $*$ denote statistical significance at the $1 \%, 5 \%$ and $10 \%$ level, respectively

1. The F-statistic of the overall significance of the equation $\left(\mathrm{H}_{0}\right.$ : all explanatory variables' coefficients are equal to zero)

2. The Hausman test. Evidence against the null hypothesis favours the fixed effects specification over random effects

3.There are missing values on independent variables MB (12 observations) and DPOR (12 observations), as well as on dependent variable ROE. For ROA, NPL and SML dependent variables, regressions address 80 observations. For the ROE regression, a further three firm-year cases have missing values

LLP (Loan loss provisions/total loans); LQ (Liquid assets/total assets); EA (Total equity/total assets); Ct/ $\mathrm{Ct}_{-1}$ (Current period's running costs/previous period's running costs); VaR (Value-at-Risk); DPOR $\mathrm{t}_{\mathrm{t}-1}$ (Dividends $\mathrm{t}_{\mathrm{t}-1} /$ net profit $\mathrm{t}_{-1}$ )*100; ForStr (Dummy for one or more foreign strategic owners); SB (Dummy for State-owned Banks); JSCB (Dummy for Joint-Stock Commercial Banks); CCB (Dummy for City Commercial Banks); TimeList (Time since IPO); MB (Market to book of net assets; S (Log of total assets); Fintech (Log of number of Fintech firms); CapMkt (Market cap of listed companies/GDP); RRR (Reserve Ratio Requirement \%); INF (Inflation rate); and LIR-SIR (Long-short term interest rate) 
Table 10 GMM estimation results for the subsample of Fintech entities

\begin{tabular}{|c|c|c|c|c|c|c|c|c|}
\hline & \multicolumn{2}{|l|}{ ROA } & \multicolumn{2}{|l|}{ ROE } & \multicolumn{2}{|l|}{ NPL } & \multicolumn{2}{|l|}{ SML } \\
\hline & Coef & t-stat & Coef & t-stat & Coef & t-stat & Coef & t-stat \\
\hline Intercept & $-0.2256^{* *}$ & -2.69 & $-0.5594^{* * *}$ & -2.50 & $0.0233^{* * *} *$ & 3.08 & $0.0257 * * *$ & 2.11 \\
\hline Dependent $_{t}$ & $-\Gamma^{0.0086^{* *}}$ & -2.66 & $-0.0151 * * *$ & -3.48 & $0.0096^{* * *}$ & 3.97 & 0.0033 & 1.48 \\
\hline \multicolumn{9}{|l|}{$\begin{array}{l}\text { Firm-spe- } \\
\quad \text { cific vari- } \\
\quad \text { ables }\end{array}$} \\
\hline LLP & $-0.0267^{*}$ & -2.05 & $-0.0455^{*}$ & -1.87 & $0.0531 * * *$ & 4.18 & $0.4360 * * *$ & 8.84 \\
\hline LQ & -0.0089 & -1.20 & -0.0310 & -1.60 & $-0.0163 *$ & -1.86 & -0.0249 & -1.28 \\
\hline $\mathrm{EA}_{\mathrm{a}}$ & $0.0195^{* *}$ & 2.76 & $0.0271 * *$ & 2.05 & $0.0225^{* *}$ & 2.48 & 0.0307 & 1.37 \\
\hline $\mathrm{C}_{\mathrm{t}} / \mathrm{C}_{\mathrm{t}-1}$ & $-0.0036^{* * *}$ & -3.18 & -0.0059 & -1.50 & -0.0082 & -1.58 & $0.0027 * * *$ & 3.00 \\
\hline VaR & $0.000019^{*}$ & 1.89 & $0.000031^{* *}$ & 2.22 & $-0.000075^{* *}$ & -2.36 & $-0.000083^{* * *}$ & -4.50 \\
\hline DPOR & -0.0224 & -1.33 & $-0.0537^{*}$ & -1.84 & -0.0099 & -1.62 & $-0.0123^{*}$ & -1.81 \\
\hline Timelist & $0.1037 *$ & 1.77 & 0.1458 & 1.55 & $0.0093^{* *}$ & 2.66 & -0.0297 & -1.63 \\
\hline MB & $-0.0036^{* * *}$ & -5.96 & $-0.0096^{* * *}$ & -6.27 & 0.0008 & 1.62 & 0.0012 & 1.23 \\
\hline S & $0.0078 * *$ & 2.30 & $0.0069 * * *$ & 3.37 & $0.0010^{* *}$ & 2.21 & $0.0014^{* *}$ & 2.64 \\
\hline \multicolumn{9}{|l|}{$\begin{array}{l}\text { Industry- } \\
\quad \text { specific } \\
\text { variables }\end{array}$} \\
\hline Ln(Fintech) & $-0.0143^{*}$ & -1.94 & -0.0787 & -1.10 & 0.0027 & 1.30 & 0.0091 & 1.18 \\
\hline CapMkt & 0.0344 & 1.56 & $0.0489 * * *$ & 2.20 & $-0.0417 *$ & -2.03 & $-0.0591 * * *$ & -3.65 \\
\hline \multicolumn{9}{|l|}{$\begin{array}{l}\text { Macro- } \\
\text { economic } \\
\text { variables }\end{array}$} \\
\hline RRR & $0.0347 * * *$ & 3.62 & $0.0437 *$ & 1.85 & $0.0186^{* * *}$ & 3.48 & $0.0190 * * *$ & 4.93 \\
\hline INF & 0.0433 & 1.07 & 0.0996 & 1.04 & $0.0708^{* *}$ & 2.39 & $0.0995^{* * *}$ & 4.36 \\
\hline LIR-SIR & $0.0822 *$ & 1.84 & $0.1301 *$ & 1.98 & $-0.2019 * * *$ & -3.65 & $-0.2932 * * *$ & -3.66 \\
\hline F-test ${ }_{1}$ & $316.34 * * *$ & & $167.10 * * *$ & & $269.48 * * *$ & & $233.27 * * *$ & \\
\hline $\operatorname{Sargan}_{2}$ & 78.12 & & 67.64 & & 53.10 & & 33.10 & \\
\hline $\operatorname{AR}(1)_{3}$ & $\mathrm{Z}=-3.83$ & $\mathrm{P}=0.000$ & $Z=-2.96$ & $\mathrm{P}=0.003$ & $Z=-4.89$ & $\mathrm{P}=0.000$ & $\mathrm{Z}=-3.38$ & $\mathrm{P}=0.001$ \\
\hline $\operatorname{AR}(2)_{4}$ & $\mathrm{Z}=-1.19$ & $P=0.234$ & $Z=-1.07$ & $P=0.284$ & $Z=-0.94$ & $P=0.347$ & $Z=-0.78$ & $\mathrm{P}=0.434$ \\
\hline No. of obs & 80 & & 77 & & 80 & & 80 & \\
\hline
\end{tabular}

$* * *, * *$ and $*$ denote statistical significance at the $1 \%, 5 \%$ and $10 \%$ level, respectively

a. The endogenous variable is instrumented using levels lagged by two periods

1. The F-statistic of the overall significance of the equation $\left(\mathrm{H}_{0}\right.$ : all explanatory variables' coefficients are equal to zero)

2. The test for over-identifying restrictions in GMM dynamic model estimation

3. Arellano-Bond test that average auto-covariance in residuals of order 1 is $0\left(\mathrm{H}_{0}\right.$ : no autocorrelation)

4. Arellano-Bond test that average auto-covariance in residuals of order 2 is $0\left(\mathrm{H}_{0}\right.$ : no autocorrelation)

5.See Note 3 in Table 9 for details on available firm-year cases for each regression

LLP (Loan loss provisions/total loans); LQ (Liquid assets/total assets); EA (Total equity/total assets); Ct/ $\mathrm{Ct}_{-1}$ (Current period's running costs/previous period's running costs); VaR (Value-at-Risk); DPOR ${ }_{\mathrm{t}-1}$ (Dividends ${ }_{\mathrm{t}-1} /$ net profit $_{\mathrm{t}-1}$ )*100; ForStr (Dummy for one or more foreign strategic owners); SB (Dummy for State-owned Banks); JSCB (Dummy for Joint-Stock Commercial Banks); CCB (Dummy for City Commercial Banks); TimeList (Time since IPO); MB (Market to book of net assets; S (Log of total assets); Fintech (Log of number of Fintech firms); CapMkt (Market cap of listed companies/GDP); RRR (Reserve Ratio Requirement \%); INF (Inflation rate); and LIR-SIR (Long-short term interest rate) 
of equity market development in supporting Chinese bank profitability during the predigitalization era.

A range of other important effects are also evident in Tables 9, 10. In particular, Fintech entities with higher MB valuations significantly underperform in ROE terms. Second, rising Fintech competition significantly erodes the ROA performance of online lenders. Third, online lenders' financial and prudential performance significantly weakens as the differential between long- and short-term interest rates narrows. Such results highlight Fintech entrants' particular vulnerability to macroeconomic and regulatory changes impacting term structure.

In a final area of analysis, we consider within-sample differences in traditional banks' Fintech proficiencies. While virtually all of China's major lenders have developed Fintech expertise, only six within the traditional bank sample had developed "wholly-owned fintech" entities (Lee 2019) within the 2013-19 study period. We consider this group of six separately via dummy HP6 (=1 for banks with High Proficiency in Fintech). As with Lee (2019), we regard this cohort as Fintech leaders among traditional banks. Nine banks within the co-joined State Bank (SB) and Joint Stock Commercial Bank (JSCB) domain reside outside this group of six. Dummy LP9 (=1 for banks with Lower Proficiency Fintech) characterizes such lenders. The third dummy (CCB) captures City Commercial banks. China Banking News (2019) reports that municipal banks, which include CCBs, as well as other regional lenders, generally suffer from one or more deficiencies in relation to core Fintech capabilities. Consequently, we categorize CCBs into a third group in which Fintech capabilities generally rank behind the LP9 group. The omitted dummy (=3 banks) is for Rural Commercial Banks (RCBs), which we assume to have very low Fintech proficiencies.

If Fintech capability is an overarching weapon against disruption and loss of market share, one would expect stronger financial and prudential performance in the HP6 group. Descriptive statistics in Table 13 generally support this contention. The HP6 cohort has slightly higher mean ROA and ROE levels relative to the LP9 group. Similarly, NPL and SML rates appear slightly lower for the HP6 cohort. Moreover, and as shown in Fig. 2, the positive mean difference in financial returns between HP6 and LP9 groups, has grown in recent years. However, a significant performance gap is not apparent in multivariate analysis (see Table 14). Nonetheless, the preliminary evidence in Table 13 (Fig. 2) points to an emerging gap in the financial returns of HP6 and LP9 bank entities. Learning and implementation lags may mean that the performance benefits of Fintech adoption only become obvious over long-run horizons.

\section{Conclusions}

The present investigation assesses the financial and prudential performance of major Chinese lenders during the 2013-2019 period of Fintech disruption. For this purpose, we consider two distinct groups of stock: (1) The country's 40 leading exchange-traded banks; and (2) a select band of 25 listed Fintech entities with dominant business presence in China. Within the 2013-2019 period of disruption, traditional banks faced major challenge from online lenders. The current inquiry assesses the financial and prudential success of both incumbent $(n=40)$ and new entrants $(n=25)$ in the Chinese credit market during this period of momentous change. 
The present enterprise highlights incumbent banks' successful adaptation to digitalization applications and processes. Through this lens, we extend and develop the extant literature on Chinese bank performance (see, among others, García-Herrero et al. 2009; Bailey et al. 2011; Tan and Flores 2013; Li and Wang 2015; Tan 2016; and Fang et al. 2019) in a number of substantive ways. First, and at a fundamental level, we widen the canvass by benchmarking incumbent Chinese banks against emerging Fintech players. Second, we identify bank-specific characteristics necessary for retention and growth of market share in the unfolding Fintech era. Third, we extend the existing academic narrative by assessing performance in both financial and prudential terms.

From analysis of incumbent players and new Fintech entrants to China's credit market, we uncover a range of noteworthy findings. Among other things, incumbent banks' financial and prudential performance generally weakened over the course of the 2013-19 period. However, there is some evidence of stabilization in performance towards the latter part of the study period. In contrast, Fintech lenders generated highly volatile financial returns but experienced marked and protracted declines in prudential performance throughout the study period. This trend is reflected in both Special Mention (SML) and Non-Performing Loan (NPL) rates. As an indicator, for the 40 traditional Chinese banks, mean NPL rates shifted from $0.93 \%$ to $1.52 \%$ between the 2013 and 2019 financial year-ends. For the 25 Fintech lenders, the adjustment was far more dramatic, with mean NPL rates surging from $2.06 \%$ to $4.93 \%$ over the study period. In financial return terms, both online lenders and traditional banks benefit from higher $\mathrm{VaR}$ and equity capital ratios.

In relation to Chinese bank performance, we observe that ROA and ROE levels exhibit strong inverse (positive) association with loan loss provisions and liquidity (equity capital) ratios. However, larger banks exhibit greater resilience in financial and prudential performance terms. Incumbent banks with foreign strategic owners and excess equity capital fared worse in loan quality terms (as evident from their higher NPL positions). Notwithstanding such findings, NPL rates were lower (and asset quality higher) in traditional banks accommodating more growth options and distributing a larger fraction of profit as dividend. Time since IPO is also important. Our evidence suggests banks pitch IPOs on rising earnings. Findings are congruent with significant asset reorganization in the lead up to IPO, most especially the sale of NPLs to China's AMCs and the dilution of remaining delinquent loans through recapitalization (McGuinness and Keasey 2010).

As China is at the very forefront of the digitalization process, present study findings offer prescriptive value for both traditional banks and online lenders in other settings. However, China's unique regulatory, institutional and political structure strongly undergirds findings in the current inquiry. For example, Chinese banks with central regulatory parties as owners benefit from major resource, funding and technology access. Such advantage serves in staving-off Fintech competition. State-owned banks also have first-mover advantage in the deployment of Fintech (Cheng and Qu 2020). China's top-four banks' pivotal position in testing digital currency payment applications (Zhou 2020) offers a topical and important data point.

\section{Appendix}

See Tables 11, 12, 13, 14, 15, 16.

See Fig. 2 
Table 11 Place and date of stock exchange listing and company website details of the Fintech subsample

\begin{tabular}{|c|c|c|c|}
\hline & Place of stock exchange listing & Listing date & Company (or SEC) website link \\
\hline XINLIJINRONG (1) & Shanghai Stock exchange & $08 / 12 / 2000$ & http://www.xinlijinrong.cn \\
\hline HUIFUTIANXIA & HKEX & $15 / 06 / 2018$ & https://www.huifu.com \\
\hline 51XINYONGKA & HKEX & $13 / 07 / 2018$ & http://u51.com \\
\hline WEIXINJINKE & HKEX & $21 / 06 / 2018$ & https://www.vcredit.com \\
\hline ZUOLICHUANGKE & HKEX & $13 / 01 / 2015$ & http://www.zlkcxd.cn \\
\hline FANHUAJINRONG & NYSE & $07 / 11 / 2018$ & $\begin{array}{l}\text { http://www.cashchina.cn/produ } \\
\text { ct-loan.html }\end{array}$ \\
\hline YIRENDAI & NYSE & $18 / 12 / 2015$ & https://www.yirendai.com \\
\hline QUDIAN & NYSE & $18 / 10 / 2017$ & $\begin{array}{l}\text { https://qudianinc.gcs-web.com/ } \\
\text { zh-hans }\end{array}$ \\
\hline XINER'FU & NYSE & $28 / 04 / 2017$ & https://www.crfchina.com \\
\hline WEIDAI & NYSE & $15 / 11 / 2018$ & https://www.weidai.com.cn \\
\hline XIAOYINGLICAI & NYSE & $19 / 09 / 2018$ & https://www.xiaoyinggroup.com \\
\hline XINYEKEJI & NYSE & $10 / 11 / 2017$ & https://finvgroup.com \\
\hline NUOYACAIFU & NYSE & $10 / 11 / 2010$ & $\begin{array}{l}\text { http://www.noahgroup.com/servi } \\
\text { ce\#service- } 4\end{array}$ \\
\hline HEXINDAI & NASDAQ & $03 / 11 / 2017$ & https://www.hexindai.com \\
\hline 360JINRONG & NASDAQ & $14 / 12 / 2018$ & https://www.360shuke.com \\
\hline LEXIN & NASDAQ & $21 / 12 / 2016$ & https://www.lexin.com \\
\hline PINTAI & NASDAQ & $25 / 10 / 2018$ & https://www.pintec.com \\
\hline YINKEKONGGU (2) & NASDAQ & $27 / 04 / 2016$ & https://www.yintech.cn \\
\hline JIAYINJINKE & $\begin{array}{l}\text { NASDAQ (NEEQ CN, } \\
12 / 2015-07 / 03 / 2019 \text { ) }\end{array}$ & $11 / 05 / 2019$ & http://www.jiayinfintech.cn \\
\hline RONG360 & NYSE & $16 / 11 / 2017$ & https://www.rong360.com \\
\hline AIHONGSEN & NASDAQ & $19 / 03 / 2018$ & https://ihongsen.com \\
\hline SHENGYINGXIN & NASDAQ & 08/08/2017 & $\begin{array}{l}\text { https://sec.report/CIK/00016 } \\
87542\end{array}$ \\
\hline JIUFUSHUKE & NASDAQ & $15 / 08 / 2019$ & https://www.9fgroup.com \\
\hline DUNXIN & NYSE & $24 / 08 / 2018$ & $\begin{array}{l}\text { https://sec.report/CIK/00014 } \\
99494\end{array}$ \\
\hline ZHONGGUODAIKUAN & NASDAQ & $22 / 10 / 2014$ & http://www.chinalending.com \\
\hline
\end{tabular}

(1) This company listed in 2000. At that point of time, it was wholly focused on the cement industry. In more recent times the company changed its main focus and has since 27/01/2015 reported to the Shanghai Stock Exchange as a Fintech entity (see pages 102-103 \& 135-136 of the company's 2019 annual report: http://www.xinlijinrong.cn/upload/file/20200420/20200420171365986598.pdf

(2) From Yintech's website (https://www.yintech.cn/business.html), the company offers a range of savings and investment products. Details of the company's "Credit risk" are available at Page 99 of its 2019 annual report: https://sec.report/Document/0001104659-20-051198/ 
Table 12 Fisher panel unit root tests

\begin{tabular}{llllll}
\hline & \multicolumn{2}{l}{ Traditional banks } & & & Fintech \\
\cline { 2 - 3 } \cline { 5 - 6 } & Test-statistics & P-values & & Test-statistics & $P$-values \\
\hline ROA & 160.76 & $<0.001$ & 90.37 & $<0.001$ \\
ROE & 201.38 & $<0.001$ & 102.67 & $<0.001$ \\
NPL & 102.50 & $<0.001$ & 105.88 & $<0.001$ \\
SML & 107.69 & $<0.001$ & 108.95 & $<0.001$ \\
LLP & 268.11 & $<0.001$ & 104.43 & $<0.001$ \\
LQ & 170.92 & $<0.001$ & 143.57 & $<0.001$ \\
EA & 160.94 & $<0.001$ & & 108.25 & $<0.001$ \\
Ct/Ct-1 & 122.17 & $<0.001$ & 97.19 & $<0.001$ \\
VaR & 111.28 & $<0.001$ & 187.42 & $<0.001$ \\
MB & 166.52 & $<0.001$ & 103.71 & $<0.001$ \\
S & 41.23 & 0.0832 & 68.18 & $<0.001$ \\
TimeList & 75.34 & $<0.001$ & 94.56 & $<0.001$ \\
DPOR & 139.94 & $<0.001$ & 113.12 & $<0.001$ \\
\hline
\end{tabular}




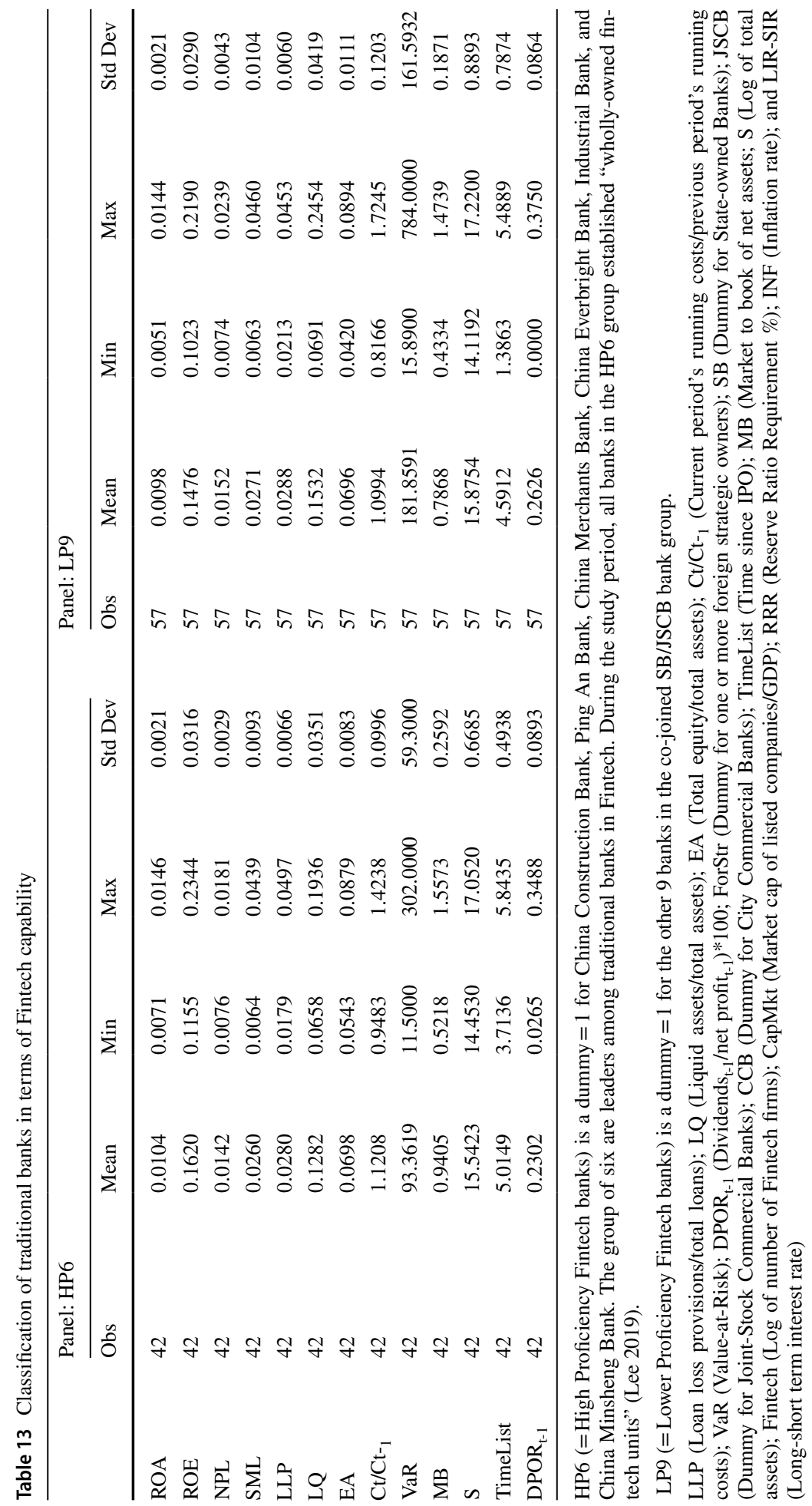




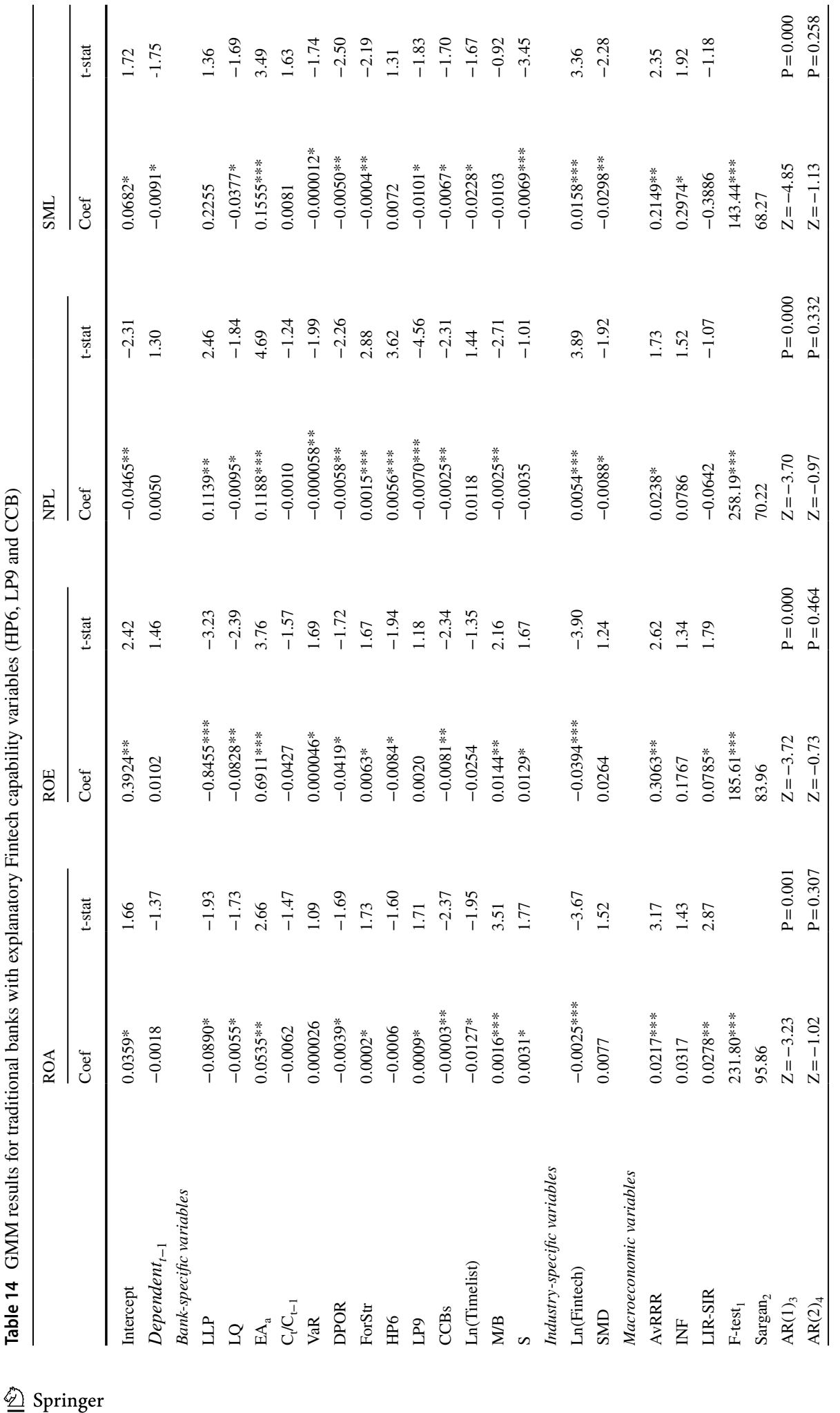




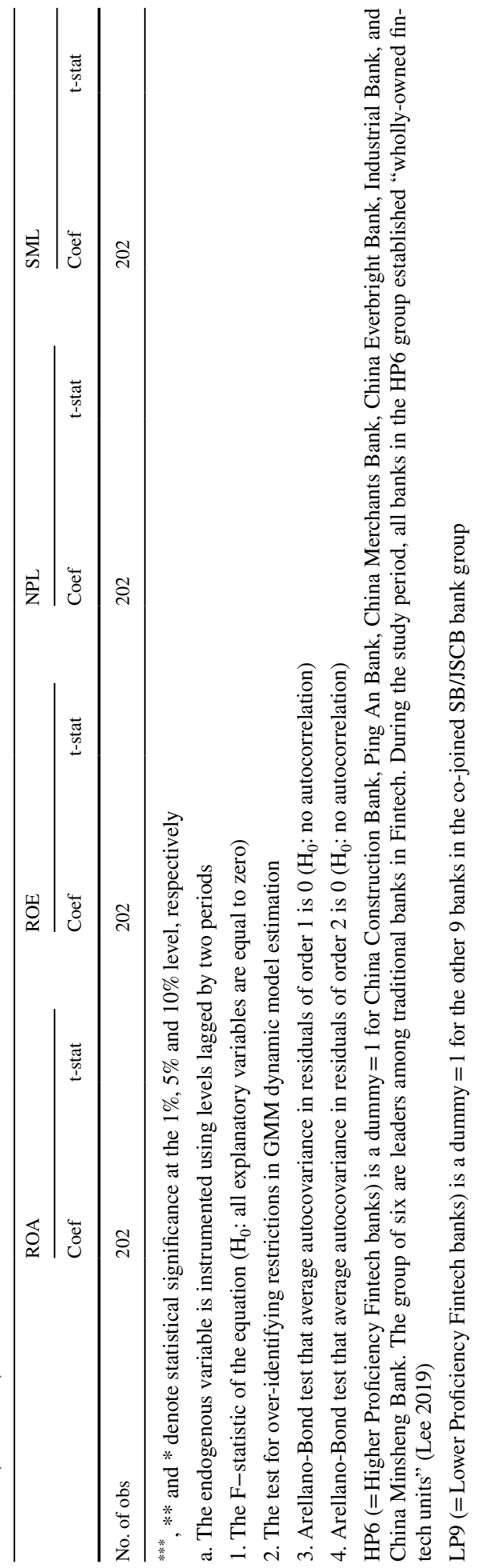




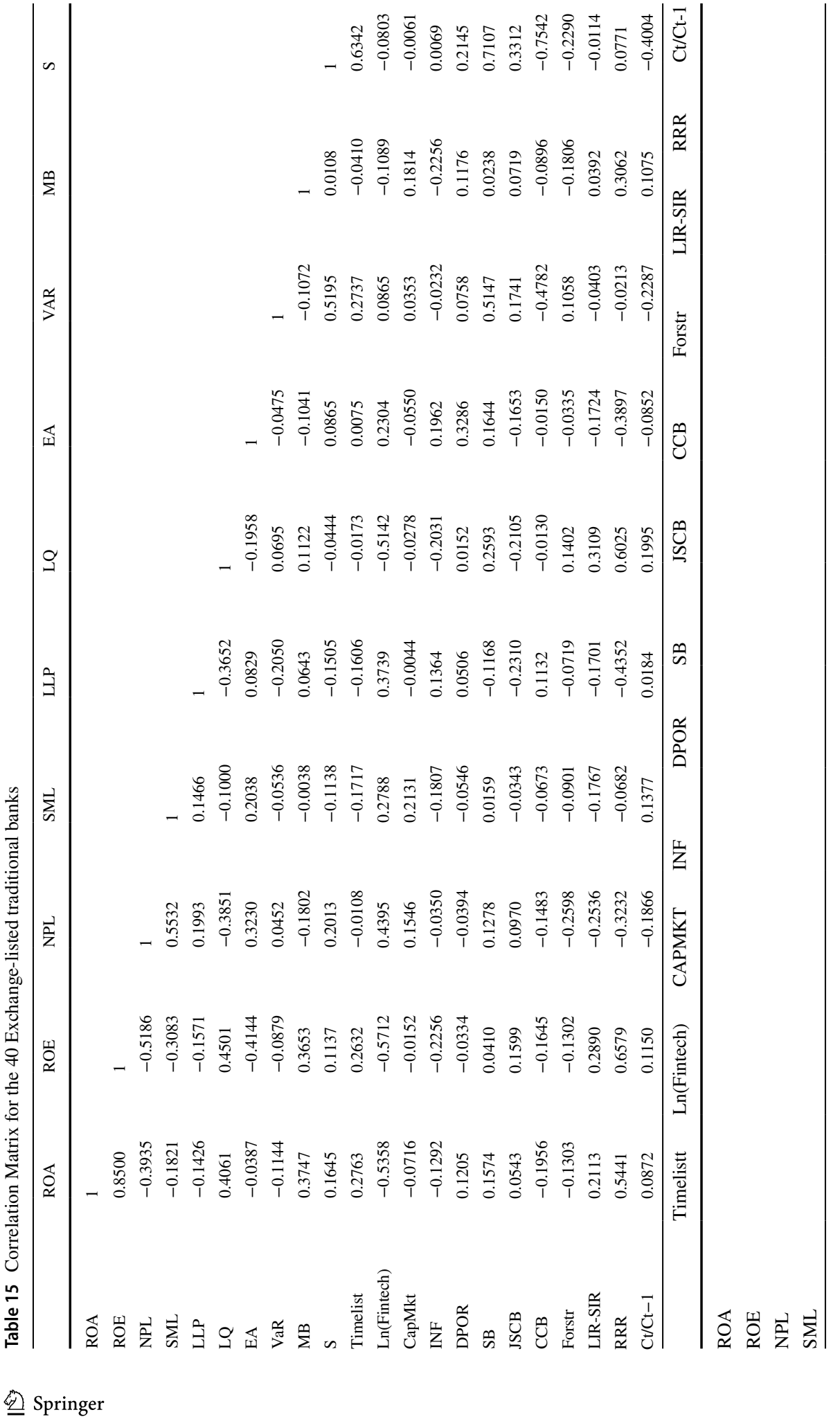




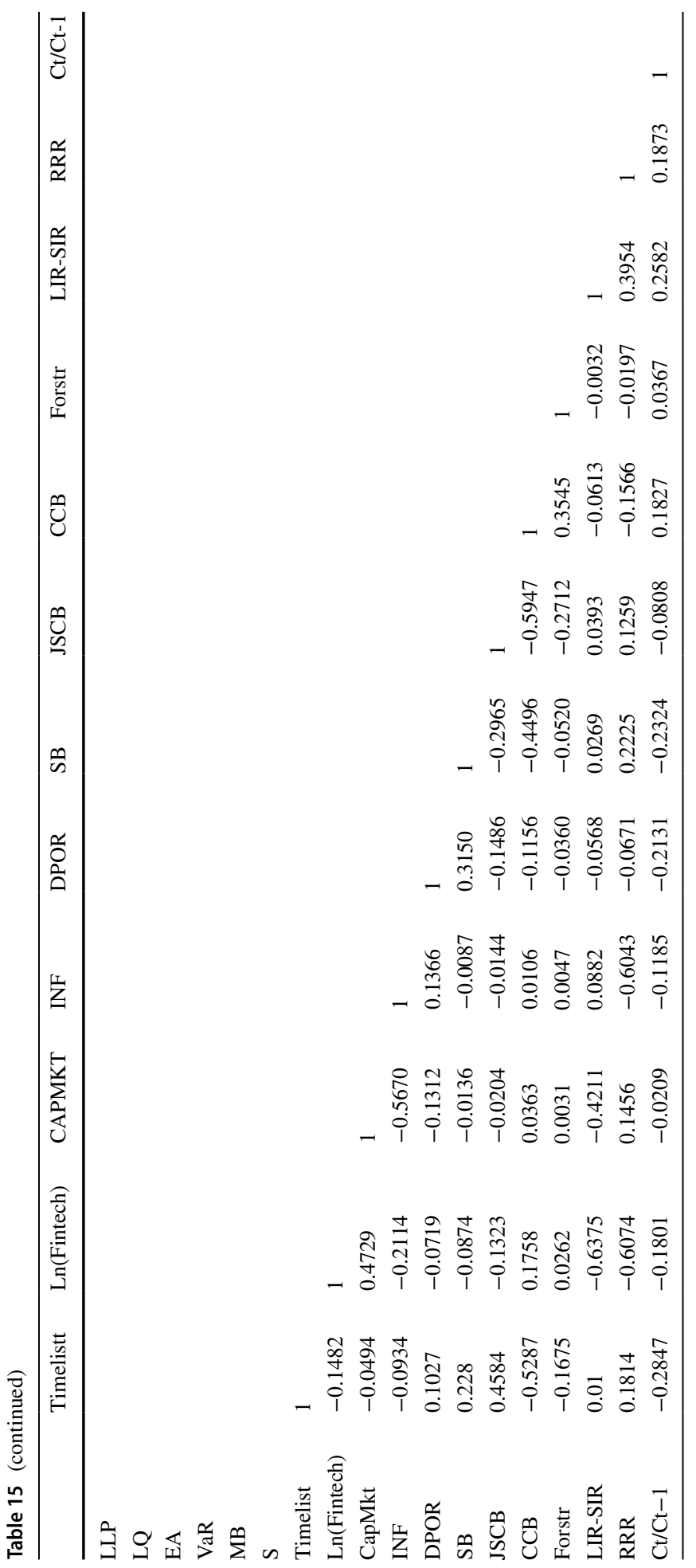


Table 16 Correlation Matrix for the 25 exchange-listed Fintech lenders

\begin{tabular}{|c|c|c|c|c|c|c|c|c|c|}
\hline & ROA & ROE & NPL & SML & LLP & LQ & EA & $\mathrm{Ct} / \mathrm{Ct}-1$ & VaR \\
\hline ROA & 1 & & & & & & & & \\
\hline ROE & 0.3736 & 1 & & & & & & & \\
\hline NPL & -0.0612 & -0.1807 & 1 & & & & & & \\
\hline SML & -0.0542 & 0.0515 & 0.5007 & 1 & & & & & \\
\hline LLP & -0.0476 & -0.1057 & 0.4716 & 0.5367 & 1 & & & & \\
\hline LQ & 0.1485 & -0.1165 & 0.0139 & -0.2898 & -0.0225 & 1 & & & \\
\hline EA & -0.0218 & 0.1072 & -0.2513 & -0.2135 & -0.2492 & 0.1469 & 1 & & \\
\hline $\mathrm{Ct} / \mathrm{Ct}-1$ & 0.0834 & 0.0593 & -0.0988 & -0.0963 & -0.0942 & 0.3362 & 0.1288 & 1 & \\
\hline VaR & 0.0916 & 0.0920 & -0.0771 & -0.0582 & -0.0488 & 0.0135 & -0.0936 & -0.0025 & 1 \\
\hline DPOR & 0.0766 & 0.0529 & -0.0592 & -0.0969 & -0.0390 & -0.0429 & 0.1190 & 0.2729 & -0.0125 \\
\hline $\mathrm{MB}$ & -0.0591 & -0.0935 & 0.2119 & -0.0721 & 0.1308 & 0.1988 & -0.0931 & -0.0483 & -0.0817 \\
\hline $\mathrm{S}$ & 0.3630 & 0.2235 & -0.1430 & 0.0848 & -0.0911 & -0.0692 & -0.1067 & 0.1690 & 0.3282 \\
\hline Timelist & -0.0451 & -0.0625 & 0.0483 & 0.0785 & 0.0027 & -0.1098 & 0.1633 & -0.0835 & -0.1659 \\
\hline CapMkt & 0.0172 & 0.1336 & -0.1014 & -0.1254 & -0.1072 & -0.0033 & 0.0261 & 0.0781 & -0.0774 \\
\hline $\operatorname{Ln}($ fintech) & -0.0371 & -0.0361 & 0.0908 & 0.1299 & 0.1010 & -0.2596 & -0.1826 & -0.1439 & 0.1416 \\
\hline INF & -0.1596 & -0.0532 & 0.0286 & 0.0468 & 0.0370 & -0.0926 & -0.0328 & -0.2168 & -0.0399 \\
\hline LIR-SIR & 0.0894 & 0.0347 & 0.0474 & -0.0180 & 0.0252 & 0.1169 & 0.0064 & 0.2371 & 0.0637 \\
\hline \multirow[t]{2}{*}{ RRR } & 0.1523 & 0.0814 & -0.0952 & -0.1041 & -0.1130 & 0.1969 & 0.1369 & 0.2486 & -0.0455 \\
\hline & DPOR & MB & $\mathrm{S}$ & Timelist & CAPMKT & $\operatorname{Ln}($ fintech $)$ & INF & LIR-SIR & RRR \\
\hline \multicolumn{10}{|l|}{ ROA } \\
\hline \multicolumn{10}{|l|}{ ROE } \\
\hline \multicolumn{10}{|l|}{ NPL } \\
\hline \multicolumn{10}{|l|}{ SML } \\
\hline \multicolumn{10}{|l|}{ LLP } \\
\hline \multicolumn{10}{|l|}{ LQ } \\
\hline \multicolumn{10}{|l|}{ EA } \\
\hline \multicolumn{10}{|l|}{$\mathrm{Ct} / \mathrm{Ct}-1$} \\
\hline \multicolumn{10}{|l|}{$\mathrm{VaR}$} \\
\hline DPOR & 1 & & & & & & & & \\
\hline MB & -0.0509 & 1 & & & & & & & \\
\hline$S$ & 0.0434 & -0.1355 & 1 & & & & & & \\
\hline Timelist & 0.1056 & 0.0683 & -0.1328 & 1 & & & & & \\
\hline CapMkt & 0.0466 & -0.1212 & -0.0759 & -0.2455 & 1 & & & & \\
\hline $\operatorname{Ln}($ fintech) & 0.0221 & 0.0361 & 0.0822 & -0.1645 & 0.1845 & 1 & & & \\
\hline INF & -0.1347 & -0.0126 & 0.0763 & 0.4129 & -0.4485 & -0.0418 & 1 & & \\
\hline LIR-SIR & -0.1274 & 0.0102 & 0.0272 & -0.2054 & 0.0292 & -0.3248 & -0.3700 & 1 & \\
\hline RRR & 0.0862 & -0.0255 & -0.1373 & -0.2583 & 0.4030 & -0.4330 & 0.4247 & 0.4393 & 1 \\
\hline
\end{tabular}



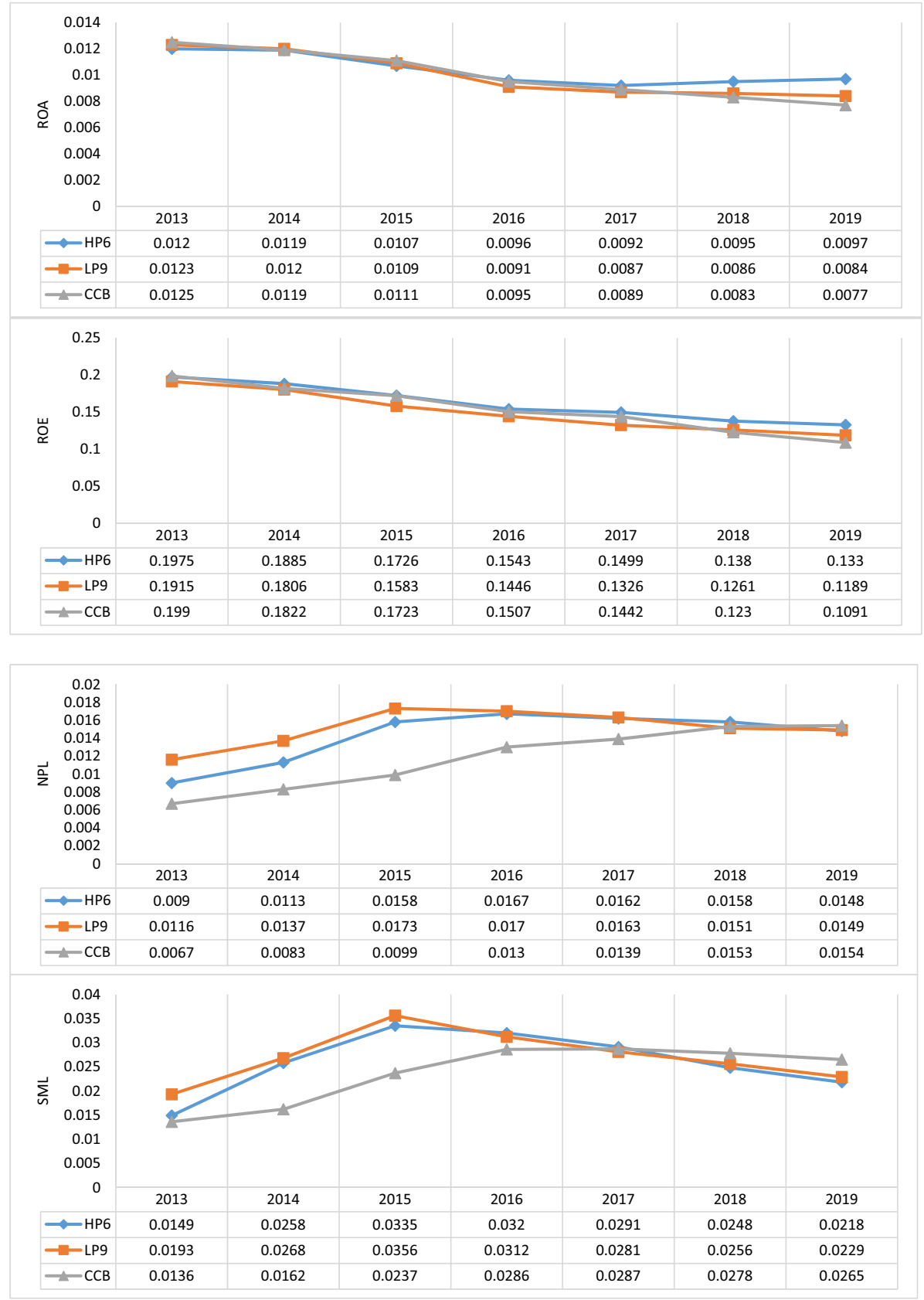

Fig. 2 Performance by study sample year (2013-19) for the HP6, LP9 and CCB groups 
Acknowledgements We wish to thank two anonymous reviewers for their comments. We also acknowledge Teresa Brunsdon for comments on an earlier draft of this paper.

Open Access This article is licensed under a Creative Commons Attribution 4.0 International License, which permits use, sharing, adaptation, distribution and reproduction in any medium or format, as long as you give appropriate credit to the original author(s) and the source, provide a link to the Creative Commons licence, and indicate if changes were made. The images or other third party material in this article are included in the article's Creative Commons licence, unless indicated otherwise in a credit line to the material. If material is not included in the article's Creative Commons licence and your intended use is not permitted by statutory regulation or exceeds the permitted use, you will need to obtain permission directly from the copyright holder. To view a copy of this licence, visit http://creativecommons.org/licenses/by/4.0/.

\section{References}

Aebi V, Sabato G, Schmid M (2012) Risk management, corporate governance, and bank performance in the financial crisis. J Bank Finance 36(12):3213-3226

Aggarwal N (2020) Banks adopt diverse strategic approaches towards fintech. Asian Banker, 31, 2020

Agoraki MEK, Delis MD, Pasiouras F (2011) Regulations, competition and bank risk-taking in transition countries. J Financ Stab 7(1):38-48

Aharony J, Jevons-Lee CW, Wong TJ (2000) Financial packaging of IPO firms in China. J Account Res 38(1):103-126

Aharony J, Swary I (1980) Quarterly dividends and earnings announcements and stockholders' returns: an empirical analysis. J Finance 35:1-12

Akin Gump (2020) China Fintech - the beginning of a new regulatory era?: https://www.akingump.com/a/ web/kJbZ4MfzujfErQgN3k3Vif/24txY3/asia-alert_china-fintech-regulation-update.pdf.

Aldama, Z., (2017) Going cash free: Why China is light years ahead in the payment revolution. South China Morning Post, 9 September 2017.

Allen D (2016) The future of China's Fintech boom. ReachFurther, EastWestBank, 1 September 2016.

Altunbas Y, Carbo S, Gardener EP, Molyneux P (2007) Examining the relationships between capital, risk and efficiency in European banking. Eur Financ Manag 13(1):49-70

Altunbas Y, Evans L, Molyneux, P (2001) Bank ownership and efficiency. J Money, Credit and Bank pp.926-954

Altunbas Y, Liu MH, Molyneux P, Seth R (2000) Efficiency and risk in Japanese banking. J Bank Finance 24(10):1605-1628

Arellano M, Bond S (1991) Some tests of specification for panel data: Monte Carlo evidence and an application to employment equations. Rev Econ Stud 58(2):277-297

Athanasoglou P, Delis M, Staikouras C (2006) Determinants of bank profitability in the South Eastern European region

Athanasoglou PP, Brissimis SN, Delis MD (2008) Bank-specific, industry-specific and macroeconomic determinants of bank profitability. J Int Finan Markets Inst Money 18(2):121-136

Bailey W, Huang W, Yang Z (2011) Bank loans with Chinese characteristics: Some evidence on inside debt in a state-controlled banking system. J Financial Quant Anal 46(6):1795-1830

Bain \& Co. (2019) As retail banks leak value, here's how they can stop it. Bain \& Company (available at www.bain.com)

Balasubramanian B, Lee J (2008) Firm age and innovation. Ind Corp Chang 17:1019-1047

Ball R, Shivakumar L (2008) Earnings quality at initial public offerings. J Account Econ 45:324-349

Barakat A, Hussainey K (2013) Bank governance, regulation, supervision, and risk reporting: evidence from operational risk disclosures in European banks. Int Rev Financ Anal 30:254-273

Basel Committee on Banking Supervision (1999) Principles for the Management of Credit Risk, July. https://www.bis.org/publ/bcbs54.pdf

Basel Committee on Banking Supervision (2002) Overview paper for impact study. Report to the bank for international settlements, October. https://www.bis.org/bcbs/qis/qis3ovrv.pdf

Basel Committee on Banking Supervision (2008) Liquidity risk: management and supervisory challenges, February. https://www.bis.org/publ/bcbs136.pdf

Basel Committee on Banking Supervision (2011) Principles for the sound management of operational risk, June. https://www.bis.org/publ/bcbs195.pdf 
Basel Committee on Banking Supervision (2019a) SRP Supervisory review process SRP30 Risk management, December. https://www.bis.org/basel_framework/chapter/SRP/30.htm

Basel Committee on Banking Supervision (2019b) The market risk framework in brief, January. https:// www.bis.org/bcbs/publ/d457_inbrief.pdf

BIS (2020) Policy responses to fintech: a cross-country overview. Bank for International Settlements: https://www.bis.org/fsi/publ/insights23.pdf.

Benesh G, Keown A, Pinkerton J (1984) An examination of market reaction to substantial shifts in dividend policy. J Financial Res 7(2):131-142

Berger AN, DeYoung R (1997) Problem loans and cost efficiency in commercial banks. J Bank Finance 21(6):849-870

Bourke P (1989) Concentration and other determinants of bank profitability in Europe, North America and Australia. J Bank Finance 13(1):65-79

Brissimis SN, Delis MD, Papanikolaou NI (2008) Exploring the nexus between banking sector reform and performance: evidence from newly acceded EU countries. J Bank Finance 32(12):2674-2683

Cai J (2014) Chinese banks drop below book value. South China Morning Post, 21 January 2014 (available at: https://www.scmp.com/business/banking-finance/article/1409919/chine se-banks-drop-below-book-value.

Caixin (2020) Exclusive: Chinese banks told to shrink loan-loss provisions and lend more: https://www. caixinglobal.com/2020-06-10/exclusive-chinese-banks-told-to-shrink-loan-loss-provisions-andlend-more-101565162.html.

Chang C, Liu Z, Spiegel MM, Zhang J (2019) Reserve requirements and optimal Chinese stabilization policy. J Monet Econ 103:33-51

Charest G (1978) Dividend information, stock returns and market efficiency - II. J Financ Econ 6:297-330

Chen H, Chow K, Tillmann P (2017) The effectiveness of monetary policy in China: evidence from a Qual VAR. China Econ Rev 43:216-231

Chen JJ, Zhang H (2014) The impact of the corporate governance code on earnings management - Evidence from Chinese listed companies. Eur Financ Manag 20:596-632

Cheng M, Geng H, Zhang J (2016) Chinese commercial banks: Benefits from foreign strategic investors. Pac Basin Financ J 40:147-172

Cheng M, Qu Y (2020) Does bank FinTech reduce credit risk? Evidence from China. Pacific-Basin Finance J 63:101398

China Banking News Editor (2019) China's municipal banks lag badly in Fintech adoption. China Banking News, 28 Feb 2019.

Chishti S, Barberis J (2016) The FINTECH Book: The financial technology handbook for investors, entrepreneurs and visionaries. Cornwall: Wiley \& Sons Ltd

Cooper MJ, Jackson WE III, Patterson GA (2003) Evidence of predictability in the cross-section of bank stock returns. J Bank Finance 27(5):817-850

Cumming DJ, Schwienbacher A (2018) Fintech venture capital. Corporate Governance: an Int Rev 26(5):374-389

Cummins JD, Lewis CM, Wei R (2006) The market value impact of operational loss events for US banks and insurers. J Bank Finance 30(10):2605-2634

Demirgüç-Kunt A, Huizinga H (2000) Financial structure and bank profitability. World Bank Policy Research Working Paper, (2430)

Dermine J (2016) Digital banking and market disruption: a sense of déjà vu? Financial Stability Rev $20: 17-23$

Dietrich A, Wanzenried G (2011) Determinants of bank profitability before and during the crisis: Evidence from Switzerland. J Int Finan Markets Inst Money 21(3):307-327

DuCharme LL, Malatesta PH, Sefcik SE (2001) Earnings management: IPO valuation and subsequent performance. J Acc Audit Financ 16(4):369-396

Eichengreen B, Gibson HD (2001) Greek banking at the dawn of the new millennium. Discussion Paper 2791, Centre for Economic Policy Research: https://cepr.org/active/publications/discussion_papers/ dp.php?dpno=2791\#.

Elliot D, Kroeber A, Qiao Y (2015) Shadow banking in China: A primer. The Brooking Institution, March 2015

EY (2019a) Listed Banks in China: 2018 Review and Outlook, Ernst \& Young, China

EY (2019b) Global FinTech Adoption Index 2019. EYGM

EY (2020) Listed banks in China: 2019 review and outlook, May 2020

Fama EF, French KR (1993) Common risk factors in the returns on stocks and bonds. J Financ Econ 33:3-56 
Fan X, Wang D, Liu L (2012) The SIFIS: "Too Big to Fail” or "Too Connected to Fail”? An analysis of China's banking sector. J Financial Res 11:16-30

Fang J, Lau CKM, Lu Z, Tan Y, Zhang H (2019) Bank performance in China: a perspective from Bank efficiency, risk-taking and market competition. Pac Basin Financ J 56:290-309

Fenech JP, Yap YK, Shafik S (2014) Can the Chinese banking system continue to grow without sacrificing loan quality? J Int Finan Markets Inst Money 31:315-330

Fiordelisi F, Marques-Ibanez D, Molyneux P (2011) Efficiency and risk in European banking. J Bank Finance 35(5):1315-1326

Forti C, Schiozer RF (2015) Bank dividends and signaling to information-sensitive depositors. J Bank Finance 56:1-11

Fiordelisi F, Soana MG, Schwizer P (2013) The determinants of reputational risk in the banking sector. J Bank Finance 37(5):1359-1371

Fisher RA (1932) Statistical methods for research workers. Oliver \& Boyd, Edinburgh, 4th Ed

Fitchratings (2020) China's tougher online lending regulation to curb risks: https://www.fitch ratings.com/research/non-bank-financial-institutions/chinas-tougher-online-lending-regul ation-to-curb-risks-22-11-2020.

Frey R, McNeil AJ (2002) VaR and expected shortfall in portfolios of dependent credit risks: conceptual and practical insights. J Bank Finance 26(7):1317-1334

García-Herrero A, Gavilá S, Santabárbara D (2009) What explains the low profitability of Chinese banks? J Bank Finance 33(11):2080-2092

Gatzert N (2015) The impact of corporate reputation and reputation damaging events on financial performance: empirical evidence from the literature. Eur Manag J 33(6):485-499

Goddard, J., Molyneux, P. and Wilson, J.O., 2004a. Dynamics of growth and profitability in banking. J Money, Credit and Bank, pp.1069-1090.

Goddard J, Molyneux P, Wilson JO (2004b) The profitability of European banks: a cross-sectional and dynamic panel analysis. Manch Sch 72(3):363-381

Gu M, Kang W, Xu B (2018) Limits of arbitrage and idiosyncratic volatility: evidence from China stock market. J Bank Finance 86:240-258

H2 Ventures \& KPMG (2019) 2019 FINTECH100: Leading global Fintech innovators: https://h2.vc/f100/\# top-50.

Haddad C, Hornuf L (2019) The emergence of the global fintech market: economic and technological determinants. Small Bus Econ 53(1):81-105

Hansen LP (1982) Large sample properties of generalized method of moments estimators. Econometrica 50(4):1029-1054

Haron S (1996) The effects of management policy on the performance of Islamic banks. Asia Pacific J Manag 13(2):63-76

Haslem JA (1968) A statistical analysis of the relative profitability of commercial banks. J Finance 23(1):167-176

He L, Chen L, Liu FH (2017) Banking reforms, performance and risk in China. Appl Econ 49:3995-4012

Huang W, Schwienbacher A, Zhao S (2012) When bank loans are bad news: evidence from market reactions to loan announcements under the risk of expropriation. J Int Finan Markets Inst Money 22:233-252

Huishang Bank Corporation Limited Annual Report (2018): http://media-hsbank.todayir.com/2019042516 400200033473551_en.pdf.

Hurun (2019) Hurun Global Unicorn List 2019 (Hurun Research Institute, 21 October 2019: https://hurun. net/EN/Article/Details?num=A38B8285034B).

Iannotta G, Nocera G, Sironi A (2007) Ownership structure, risk and performance in the European banking industry. J Bank Finance 31(7):2127-2149

Jain B, Kini O (1994) The post-issue operating performance of IPO firms. J Financ 59:1699-1726

Johnson SG, Schnatterly K, Hill AD (2013) Board composition beyond independence: Social capital, human capital and demographics. J Manag 39:232-262

Judson RA, Owen AL (1999) Estimating dynamic panel data models: a guide for macroeconomists. Econ Lett 65(1):9-15

Karpoff JM, Lee DS, Martin GS (2008) The cost to firms of cooking the books. J Financial and Quant Anal 43(3):581-611

Kerkhof J, Melenberg B, Schumacher H (2010) Model risk and capital reserves. J Bank Finance 34(1):267-279

King B (2018) Bank 4.0: Banking Everywhere, Never at a Bank. Wiley, 2019

Klein A (2019) Is China's new payment system the future? Brookings Institution, June 2019

Kohlscheen E, Murcia A, Contreras J (2018) Determinants of bank profitability in emerging markets. Bank of International Settlements, BIS Working Papers No 686 
KPMG (2018) The pulse of Fintech 2018 (https://assets.kpmg/content/dam/kpmg/xx/pdf/2019/02/the-pulseof-fintech-2018.pdf, 13/02/ 2019)

Laeven L, Ratnovski L, Tong H (2016) Bank size, capital, and systemic risk: some international evidence. J Bank Finance 69:S25-S34

Lensink R, Meesters A, Naaborg I (2008) Bank efficiency and foreign ownership: do good institutions matter? J Bank Finance 32(5):834-844

Leong C, Tan B, Xiao X, Tan FTC, Sun Y (2017) Nurturing a FinTech ecosystem: the case of a youth microloan startup in China. Int J Inf Manage 37(2):92-97

Li W, Wang SS (2015) Performance of commercial banks in China: traditional and non-traditional business, ownership type, and government interest rate policies (Pages 4-36 in Experiences and Challenges in the development of the Chinese capital market, Eds. Cumming, D., Guariglia, A., Hou, W. and Lee, E., Palgrave MacMillan)

Liang Q, Li Z, Zheng LI (2014) Systemic importance, prudential tools and China banking regulation. J Financial Res 8:32-46

Lintner J (1956) Distribution of incomes of corporations among dividends, retained earnings and taxes. Am Econom Rev 46:97-113

Ljunqvist A, Nanda V, Singh R (2006) Hot markets, investor sentiment and IPO pricing. J Bus 79:1667-1702 Loughran T, Ritter JR (1995) The new issues puzzle. J Financ 50:23-51

Luo D, Dong Y, Armitage S, Hou W (2017) The impact of foreign bank penetration on the domestic banking sector: new evidence from China. Eur J Finance 23:752-780

Luo Y, Tung RL (2007) International expansion of emerging market enterprises: a springboard perspective. J Int Bus Stud 38(4):481-498

Luong, h., Moshirian, F., Nguyen, L., Tian, X., and Zhang, B., (2017) How do foreign institutional investors enhance firm innovation? J Financial and Quant Anal 52:1449-1490

Maddala GS, Wu S (1999) A comparative study of unit root tests with panel data and a new simple test. Oxford Bull Econ Stat 61(S1):0305-9049

McAllister PH, McManus D (1993) Resolving the scale efficiency puzzle in banking. J Bank Finance 17(2-3):389-405

McGuinness PB, Keasey K (2010) The listing of Chinese state-owned commercial banks and their path to banking and ownership reform. The China Quart 201:125-155

McGuinness PB, Lam CK, Vieito JP (2015) Gender and other major board characteristics in China: explaining corporate dividend policy and governance. Asia Pacific J Manag 32:989-1038

McGuinness PB, Vieito J, Wang M (2017) The role of board gender and foreign ownership in the CSR performance of Chinese listed firms. J Corp Finan 42:75-99

McKinsey \& Co. (2014) China's digital transformation: the Internet's impact on productivity and growth. McKinsey Global Institute, July 2014.

McNulty JE, Akhigbe A (2017) What do a bank's legal expenses reveal about its internal controls and operational risk? J Financ Stab 30:181-191

Megginson WL, Ullah B, Wei Z (2014) State ownership, soft-budget constraints and cash holdings: evidence from China's privatized firms. J Bank Finance 48:276-291

Michaely R, Thaler H, Womack K (1995) Price reactions to dividend initiations and omissions Overreactions or drift. J Finance 50:573-608

Miller MH, Modigliani F (1961) Dividend policy, growth and the valuation of shares. J Bus 34:411-433

Mingkang, L. (2015) Internet finance and regulation in China, Fung Global Institute, August 2015 (Report available at: FGI-Report-Internet-Finance-part-I-Main-Report-2.pdf (hku.hk).

Molyneux P, Thornton J (1992) Determinants of European bank profitability: a note. J Bank Finance 16(6):1173-1178

Moosa IA (2007) Operational risk: a survey. Financ Mark Inst Instrum 16(4):167-200

Mukherjee N, Zambon S, Lucius H (2015) Do banks manage Reputational Risk? A case study of European Investment Bank. Working Paper.

Murphy DL, Shrieves RE, Tibbs SL (2009) Determinants of the stock price reaction to allegations of corporate misconduct: earnings, risk, and firm size effects. J Financial and Quant Anal 43(3):581-612

Neely MC, Wheelock DC (1997) Why does bank performance vary across states? Federal Reserve Bank of St Louis Rev 79(2):27

Netter, J.M. and Poulsen, A.B., 2003. Operational risk in financial service providers and the proposed Basel capital accord: an overview. In: Advances in Financial Economics (pp. 147-171). Emerald Group Publishing Limited.

Pasiouras F, Kosmidou K (2007) Factors influencing the profitability of domestic and foreign commercial banks in the European Union. Res Int Bus Financ 21(2):222-237 
Perry J, De Fontnouvelle P (2005) Measuring reputational risk: The market reaction to operational loss announcements. Available at SSRN 861364

Pfeffer J, Salancik G (1978) The external control of organizations: a resource dependence perspective. Harper \& Row, NewYork

Phan DHB, Narayan PK, Rahman RE, Hutabarat AR (2019) Do financial technology firms influence bank performance? Pacific-Basin Finance J, p.101210

Preen M (2018) China's FinTech Industry. https://www.china-briefing.com/news/chinas-fintech-industry/

Psillaki M, Tsolas IE, Margaritis D (2010) Evaluation of credit risk based on firm performance. Eur J Oper Res 201(3):873-881

PwC (2017) Global FinTech survey - China summary 2017 (available at: https://www.pwccn.com/en/ financial-services/publications/fintech/global-fintech-survey-china-summary-jun2017.pdf).

Rabinovitch, S., 2013. Chinese banks venture into ecommerce, Financial Times, 4 February 2013.

Ritter JR (1991) The long-run performance of initial public offerings. J Financ 46(1):3-27

Sam AG, Zhang X (2020) Value relevance of the new environmental enforcement regime in China. J Corporate Finance, 62 (forthcoming issue)

Sargan JD (1958) The estimation of economic relationships using instrumental variables. Econometrica 26(3):393-415

Saona P (2016) Intra-and extra-bank determinants of Latin American Banks' profitability. Int Rev Econ Financ 45:197-214

Shaban M, James GA (2018) The effects of ownership change on bank performance and risk exposure: evidence from Indonesia. J Bank Finance 88:483-497

Sharpe IG (1995) Determinants of capital structure of Australian trading banks. Asia Pacific J Manag 12(2):97-121

Shen Y, Huang Y (2016) Introduction to the special issue: Internet finance in China. China Econom J 9(3):221-224

Short BK (1979) The relation between commercial bank profit rates and banking concentration in Canada, Western Europe, and Japan. J Bank Finance 3(3):209-219

Smirlock M (1985) Evidence on the (non) relationship between concentration and profitability in banking. J Money, Credit, Bank 17(1):69-83

Statista (2020) FinTech in China (did-78834-1: https://www.statista.com/study/78834/fintech-in-china/)

Stiglitz JE (1972) Some aspects of the pure theory of corporate finance: bankruptcies and takeovers. The Bell J Econom Manag Sci, pp.458-482

Sturm P (2013) Operational and reputational risk in the European banking industry: the market reaction to operational risk events. J Econ Behav Organ 85:191-206

Sun L, Chang TP (2011) A comprehensive analysis of the effects of risk measures on bank efficiency: evidence from emerging Asian countries. J Bank Finance 35(7):1727-1735

Talavera O, Yin S, Zhang M (2018) Age diversity, directors' personal values, and bank performance. Int Rev Financ Anal 55:60-79

Tan Y, Floros C (2013) Risk, capital and efficiency in Chinese banking. J Int Finan Markets Inst Money 26:378-393

Tan Y (2016) The impacts of risk and competition on bank profitability in China. J Int Finan Markets Inst Money 40:85-110

Teoh SH, Welch I, Wong TJ (1998) Earnings management and the long-run market performance of initial public offerings. J Finance 53:1935-1974

Thomson Reuters (2020) Shareholders' rights in private and public companies in China: overview. https://uk.practicallaw.thomsonreuters.com/7-612-3807?transitionType=Default\&contextData= (sc.Default)\&firstPage $=$ true.

Wang GJ, Xie C, Zhao L, Jiang ZQ (2018) Volatility connectedness in the Chinese banking system: do state-owned commercial banks contribute more? J Int Finan Markets Inst Money 57:205-230

Wang R, Liu J, Luo H (2020) Fintech development and bank risk taking in China. The Eur J Finance, pp.1-22.

Walter I (2016) Reputational risks and large international banks. Fin Markets Portfolio Mgmt 30(1):1-17

Wang Z, Wei W, Luo J, Calderon M (2019) The effects of petroleum product price regulation on macroeconomic stability in China. Energy Policy 132:96-105

Wang Y, Xiuping S, Zhang Q (2021) Can fintech improve the efficiency of commercial banks? An analysis based on big data. Res Int Business and Finance 55:101338

Watts R (1973) The information content of dividends. J Bus 46:191-211

Welker M, Ye K, Zhang N (2017) (Un) intended consequences of a mandatory dividend payout regulation for earnings management: evidence from a natural experiment. $J$ Acc Audit Financ 32(4):510-535 
Wen F, Xiao J, Xia X, Chen B, Xiao Z, Li J (2019) Oil prices and Chinese stock market: nonlinear causality and volatility persistence. Emerg Mark Financ Trade 55(6):1247-1263

Wiersema MF, Bantel KA (1992) Top management team demography and corporate strategic change. Acad Manag J 35:91-121

Xiong X, Gao Y, Feng X (2017) Successive short-selling ban lifts and gradual price efficiency: evidence from China. Account Finance 57(5):1557-1604

Xu N, Li X, Yuan Q, Chan KC (2014) Excess perks and stock price crash risk: evidence from China. J Corp Finan 25:419-434

Xu W, Ma F, Chen W, Zhang B (2019) Asymmetric volatility spillovers between oil and stock markets: evidence from China and the United States. Energy Economics 80:310-320

Zhao K (2021) Comparative bank financial risk management models in fintech and challenger banks. Sheffield Hallam University Research Archive

Zhang D, Cai J, Dickinson DG, Kutan AM (2016) Non-performing loans, moral hazard and regulation of the Chinese commercial banking system. J Bank Finance 63:48-60

Zhang J, Jiang C, Qu B, Wang P (2013) Market concentration, risk-taking, and bank performance: evidence from emerging economies. Int Rev Financ Anal 30:149-157

Zhou C (2020) China's digital currency edges closer with large-scale test by four state-owned banks. South China Morning Post, 6 August 2020 (https://www.scmp.com/print/economy/china-economy/article/ 3096296/chinas-digital-currency-edges-closer-large-scale-test-four)

Zhou W, Arner D, Buckley RP (2015) Regulation of digital financial services in China: last mover advantage? Tsinghua China Law Rev 8:25-61

Publisher's Note Springer Nature remains neutral with regard to jurisdictional claims in published maps and institutional affiliations.

\section{Authors and Affiliations}

\section{Paraskevi Katsiampa' $\cdot$ Paul B. McGuinness ${ }^{2,3}$ (D) Jean-Philippe Serbera ${ }^{4} \cdot K_{\text {Kn }}$ Zhao $^{5}$}

Paraskevi Katsiampa

p.katsiampa@sheffield.ac.uk

Jean-Philippe Serbera

j.serbera@shu.ac.uk

Kun Zhao

zhzhaokun@cqrcb.com

1 Lecturer in Financial Management, Sheffield University Management School, The University of Sheffield, Conduit road, Sheffield S10 1FL, UK

2 Chair in Accounting and Finance, Sheffield University Management School, The University of Sheffield, Conduit Road, Sheffield S10 1FL, UK

3 Emeritus Professor, Department of Finance, Chinese University of Hong Kong, Hong Kong, China

4 Senior Lecturer in Banking \& Financial Markets, Department of Finance, Accounting \& Business Systems, Sheffield Business School, Sheffield Hallam University, Howard street, Sheffield S1 1WB, UK

5 Risk Strategy Analyst, Chongqing Rural Commercial Bank, No.36 JinshaMeng Street, JiangBei Qu, Chongqing 400020, China 